University of South Florida

DIGITAL COMMONS

@ UNIVERSITY OF SOUTH FLORIDA
Digital Commons @ University of

South Florida

$7-1-2002$

\title{
Synthesis for Transit Non-User Surveys and Appendices
}

CUTR

Follow this and additional works at: https://digitalcommons.usf.edu/cutr_nctr

\section{Recommended Citation}

"Synthesis for Transit Non-User Surveys and Appendices," National Center for Transit Research (NCTR) Report No. CUTR-NCTR-RR-2001-13, Center for Urban Transportation Research, University of South Florida, 2002.

DOI: https://doi.org/10.5038/CUTR-NCTR-RR-2001-13

Available at: https://scholarcommons.usf.edu/cutr_nctr/17

This Technical Report is brought to you for free and open access by the National Center for Transit Research (NCTR) Archive (2000-2020) at Digital Commons @ University of South Florida. It has been accepted for inclusion in Research Reports by an authorized administrator of Digital Commons @ University of South Florida. For more information, please contact digitalcommons@usf.edu. 
TRANSIT NON-USER SURVEY: Restful Riding Rather than Stressful Driving

Final Report

Prepared for:

Department of Transportation

State of Florida

By:

Center for Urban Transportation Research

College of Engineering

University of South Florida

July 2002

Page 1 of 61 pages 
TECHNICAL REPORT STANDARD TITLE PAGE

\begin{tabular}{|c|c|c|}
\hline $\begin{array}{l}\text { 1. Report No. } \\
\text { NCTR-416-08.4 }\end{array}$ & 2. Government Accession No. & 3. Recipient's Catalog No. \\
\hline \multirow{2}{*}{\multicolumn{2}{|c|}{$\begin{array}{l}\text { 4. Title and Subtitle } \\
\text { TRANSIT NON-USER SURVEY: Restful Riding Rather than Stressful } \\
\text { Driving }\end{array}$}} & $\begin{array}{l}\text { 5. Report Date } \\
\text { October } 2002\end{array}$ \\
\hline & & 6. Performing Organization Code \\
\hline $\begin{array}{l}\text { 7. Author(s) } \\
\text { Thompson, Brenda J., Perone, Jennifer S }\end{array}$ & , \& Gabourel, Kimberlee & 8. Performing Organization Report No. \\
\hline \multirow{2}{*}{\multicolumn{2}{|c|}{$\begin{array}{l}\text { 9. Performing Organization Name and Address } \\
\text { Center for Urban Transportation Research } \\
4202 \text { E. Fowler Avenue, CUT } 100 \\
\text { Tampa, FL } 33620-57350\end{array}$}} & 10. Work Unit No. \\
\hline & & $\begin{array}{l}\text { 11. Contract or Grant No. } \\
\text { DTRS98-G-00329 }\end{array}$ \\
\hline \multirow{2}{*}{\multicolumn{2}{|c|}{$\begin{array}{l}\text { 12. Sponsoring Agency Name and Address } \\
\text { Office of Research and Special Programs } \\
\text { U.S. Department of Transportation } \\
\text { Washington, DC } 20590\end{array}$}} & 13. Type of Report and Period Covered \\
\hline & & 14. Sponsoring Agency Code \\
\hline
\end{tabular}

15. Supplementary Notes

Supported by a Grant from the USDOT Research and Special Programs Administration, and the Florida Department of Transportation.

16. Abstract

This report presents information on why people do not use transit in large numbers in both the United States and the State of Florida. The report contains demographics of the non-user public according to age, gender, automobile ownership, income, and ethnicity. In addition, it contains a synthesis of Florida Transit Surveys, an examination of most appropriate questions and methodologies for data gathering, and suggestions about how to improve overall transit service so as to attract choice non-users to public transit.

17. Key Words

Transit non-users, transit ridership, demographics of transit non-users, Florida transit surveys.
18. Distribution Statement

Available to the public through the National Technical Information Service (NTIS), 5285 Port Royal Road, Springfield, VA 22161, (703) 487-4650, http://www.ntis.gov/, and through the NCTR web site at http://www.nctr.usf.edu/.

20. Security Classif. (of this page)

Unclassified

\begin{tabular}{l|l}
$\begin{array}{l}\text { 21. No. of pages } \\
61\end{array}$ & 22. Price \\
\hline
\end{tabular}




\section{Florida Department of Transportation}

605 Suwannee Street

Tallahassee, Florida

32399-0450

(904) 488-7774

Fax (904) 922-4942

Project Manager: Jon Ausman

\section{Center for Urban Transportation Research \\ University of South Florida \\ 4202 East Fowler Avenue, CUT 100 \\ Tampa, Florida \\ 33620-5350 \\ (813) 974-3120}

Suncom 574-3120

Fax (813) 974-5168

Principal Investigator: Brenda Thompson

Research Assistants: Kimberlee Gabourel and Jennifer Perone

The opinions, findings, and recommendations expressed in this report are those of the Center for Urban Transportation Research (CUTR) and the University of South Florida and not necessarily those of the Florida Department of Transportation. The U. S. government and the Florida

Department of Transportation assume no liability for the contents or use thereof.

Prepared in cooperation with the Florida Department of Transportation. 


\section{TABLE OF CONTENTS}

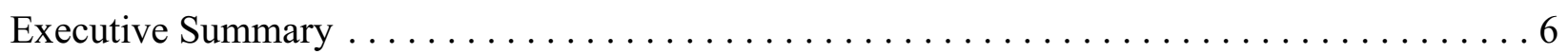

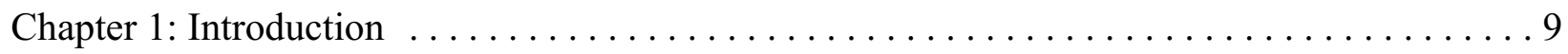

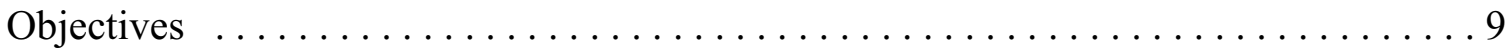

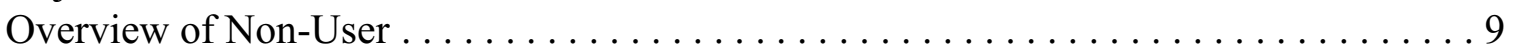

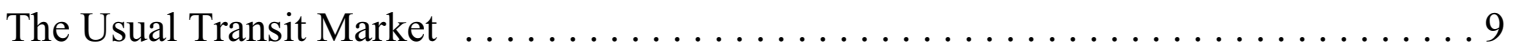

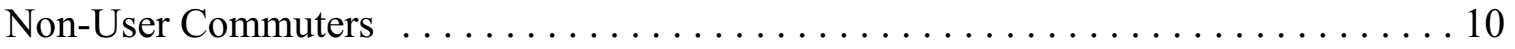

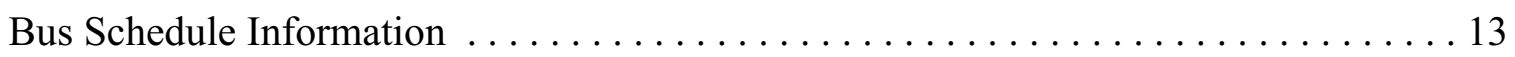

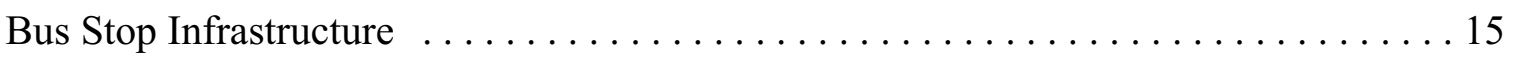

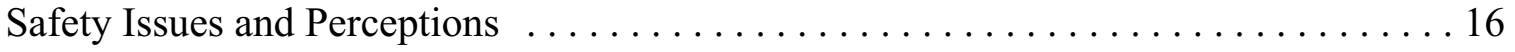

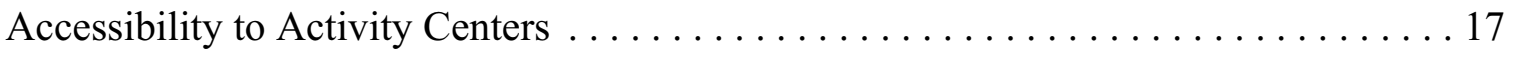

Chapter 2: Demographics of the Non-User Public $\ldots \ldots \ldots \ldots \ldots \ldots \ldots \ldots \ldots \ldots$

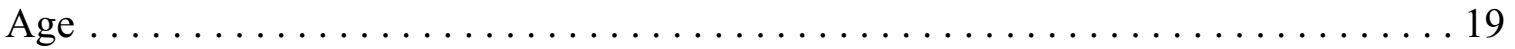

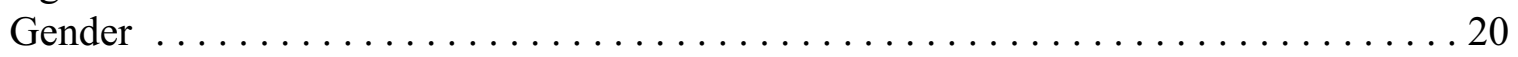

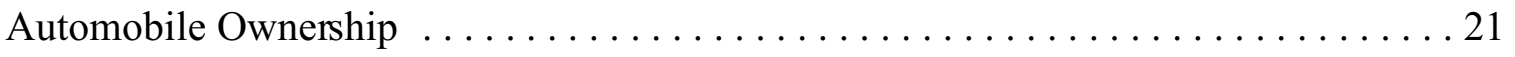

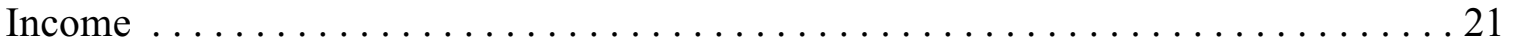

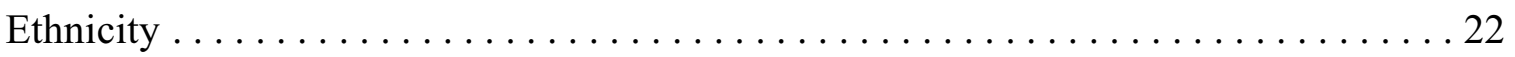

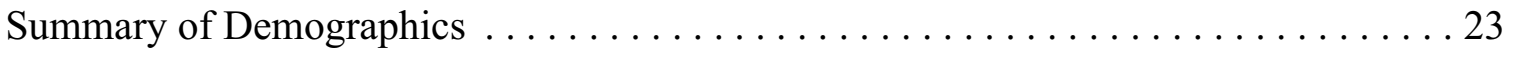

Chapter 3: Florida Community Public Transportation Surveys $\ldots \ldots \ldots \ldots \ldots \ldots \ldots$

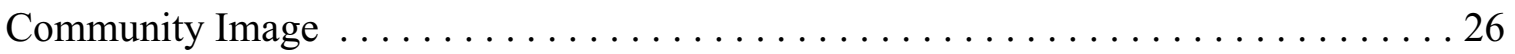

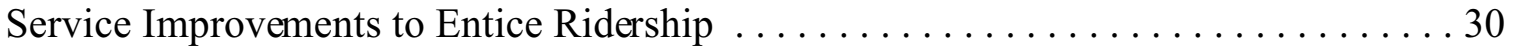

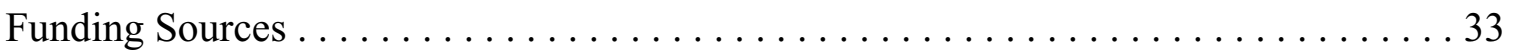

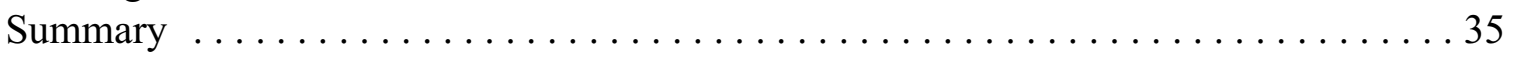

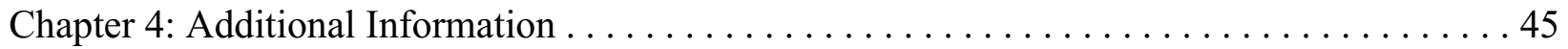

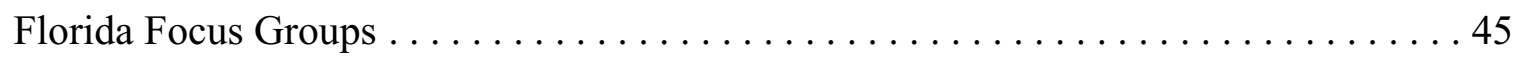

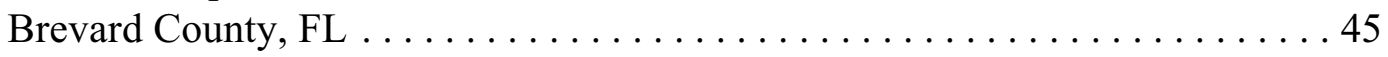

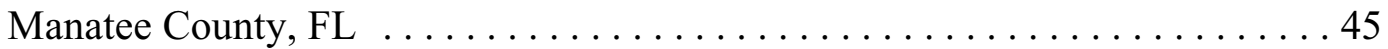

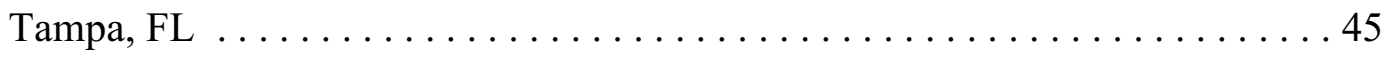

Non-Florida Studies . . . . . . . . . . . . . . . . . . . . . . . . 46

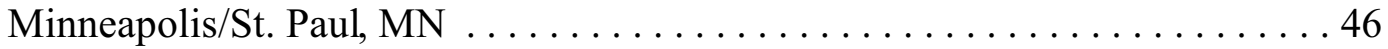

Oshkosh, Wisconsin . ........................ 47

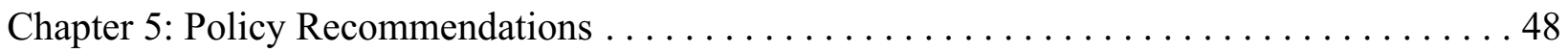

Summary of Policy Recommendations $\ldots \ldots \ldots \ldots \ldots \ldots \ldots \ldots \ldots \ldots \ldots \ldots \ldots \ldots \ldots \ldots \ldots \ldots \ldots \ldots$

Chapter 6: Survey Methodology Guidance $\ldots \ldots \ldots \ldots \ldots \ldots \ldots \ldots \ldots \ldots \ldots \ldots \ldots \ldots \ldots \ldots \ldots \ldots$

Page 3 of 61 pages 


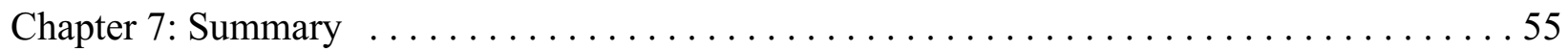

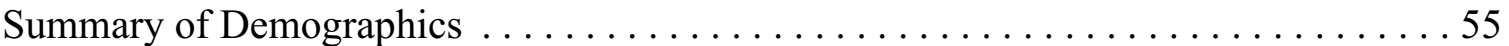

Summary of Florida Community Public Transit Surveys $\ldots \ldots \ldots \ldots \ldots \ldots \ldots$

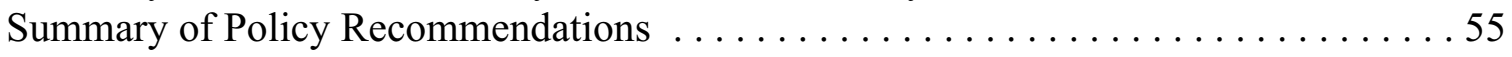

Summary of Survey Methodology Guidance $\ldots \ldots \ldots \ldots \ldots \ldots \ldots \ldots \ldots$

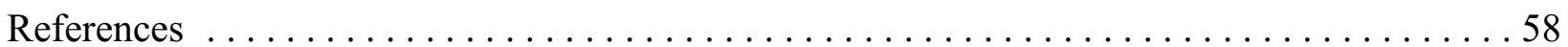

Appendix A: NPTS Data Tables

Appendix B: Florida Surveys 


\section{LIST OF TABLES}

Table A: Workers by Age Where Transit is Available . . . . . . . . . . . . . . 20

Table B: Workers by Gender Where Transit is Available . . . . . . . . . . . . . . 21

Table C: Workers by Automobile Ownership Where Transit is Available . . . . . . . . . . 21

Table D: Workers by Income Where Transit is Available . . . . . . . . . . . . . . 22

Table E: Workers by Ethnicity Where Transit is Available $\ldots \ldots \ldots \ldots \ldots \ldots \ldots \ldots$

Table F: How good a job has public transit done at providing ways to get around the

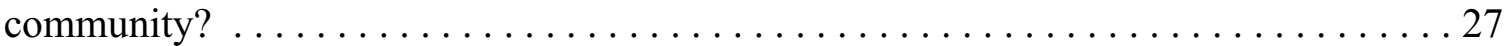

Table G: Public Transportation is Just for Those Who Cannot Afford a Car . . . . . . . . . . 29

Table H: An Effective Public Transportation System is Important for the Local Economy . . . 30

Table I: Strengths and weaknesses of data collection methods $\ldots \ldots \ldots \ldots \ldots \ldots \ldots \ldots$

\section{LIST OF FIGURES}

Figure 1: How good a job has public transit done at providing ways to get around the

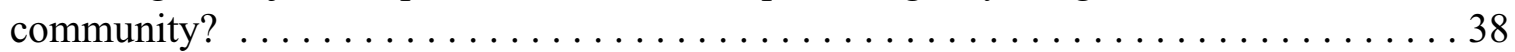

Figure 2: Public Transportation is Just for Those Who Cannot Afford a Car . . . . . . . . . 38

Figure 3: An effective Public Transportation System is Important for the Local Economy . . . 39

Figure 4: HART: Would any of the following things make you more likely to use the

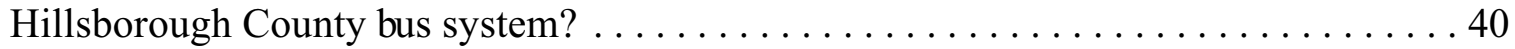

Figure 5: JTA: Would You Ride the Bus Once Per Month or More If Improvement

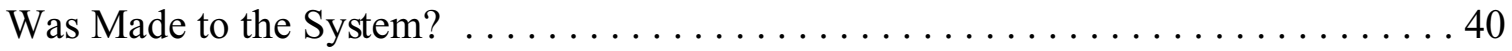

Figure 6: LYNX: What can LYNX do to Increase the Likelihood that you will use a

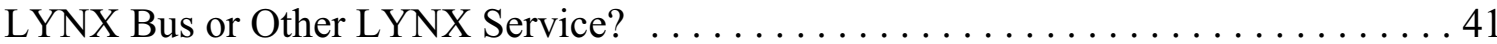

Figure 7: MDT: Would you consider using Metrobus or Metrorail in Dade County if . . . . . 41

Figure 8: MDT: Which of the potential improvements might change use of transit? . . . . . 42

Figure 9: PalmTran: Would You Ride the Bus Once Per Month or More if

Improvement Was Made to the System? . . . . . . . . . . . . . . . . . . 42

Figure 10: PSTA: If they wanted to make it worthwhile for you to use the

bus regularly, how important would it be for PSTA to each of the following? . . . . . 43

Figure 11: JTA: Percentage of Former Riders Strongly Agreeing with

Statements About Why They No Longer Use the Bus. . . . . . . . . . . . . . 44

Figure 12: PalmTran: What is the Main Reason You No Longer Ride the Bus? . . . . . . . . . 44 


\section{EXECUTIVE SUMMARY}

In transit, ridership is key. The number of trips a system carries not only produces operational revenue, but is important in generating federal, state, and local funding support, too. Often, a transit system s performance is judged primarily by ridership and the measures that compare ridership to costs or service supply. Therefore, an important goal of transit planners is to continue to find new and innovative ways to market potential riders while retaining their current patrons. Customarily, on-board customer surveys have been a staple in the data collection efforts of transit systems. Public opinion and perspectives may not match the opinions and perspectives of traditional riders. It is now becoming increasingly important

to survey non-users. If someone is not using transit service, it is in the best interest of the transit systems to determine the primary reasons for this to see if any solutions to the barriers exist. Hence, by identifying and then removing potential impediments to transit usage under their control, it may be possible for systems to increase their overall client base which in turn will boost ridership and revenues.

Although national statistics are useful as a preliminary guide, frequently local entities need to address their own markets. It is possible for considerable variations between the demographics of national and local markets. In Florida, transit ridership has grown. According to the Performance Evaluation of Florida s Public Transit Systems (1999) report, fixed-route ridership has increased 45 percent while the population has increased by nearly 40 percent from 1984 to 1999. Also, between 1998 and 1999, fixedroute ridership grew by 4.6 percent compared to approximately 2.1 percent for population growth. In Florida, transit user growth is higher than the population growth rate and over the most recent period transit ridership grew by more than twice the rate of population growth. However, the growth of ridership in Florida is due to a surge in population growth rather than by attracting choice riders. In fact, compared with other transportation options, public transit has a relatively low market share, especially when considering work-related trips. As portrayed in Chapter 2, accord ing to the 1995 NPTS household survey data, only $3 \%$ of Florida s commuters utilize transit for work where it is available. In Florida, when a family s household income becomes $\$ 15,000$ or more, the typical mode of choice for work trips is the automobile.

Although ridership is increasing, transit agencies are encountering tighter budget cons traints. Budgets have been squeezed by rising fuel and oil costs, employee overtime, costly federally-mandated demandresponse ADA service, and cutbacks in subsidies, among other hardships. While federal mandates have increased, federal funding has declined as a percentage of total transit funding from 20 percent in 1984 to 11 percent in 1999 according to the Performance Evaluation of Florida s Public Transit Systems (1999). Consequently, transit systems have to rely on a greater percentage of funding from their local community. The nine Florida community-wide surveys summarized in Chapter 3 reveal that there is support for transit. Transit is perceived to provide adequate service, enhance community transportation objectives, 
support the local economy, and raise quality of life in Florida s communities. Many of those who seem to support transit do not necessarily ride transit. Hence, they are content to provide adequate service for those who do ride it. If these non-users could be attracted to ride transit, they would prefer better geographical coverage, especially stops close to home and work. Other desired service enhancements include more span of service (holiday, weekend, nights) and frequent buses. Taxes to meet the community s transportation goals are somewhat supported, particularly if congestion is relieved and/or the community is given more transportation options. If non-users must be taxed more, they prefer a sales instead of either a gas or property tax.

Chapter 4 provides additional examples of non-user opinions by summarizing focus group discussions as well as out of state community surveys. The focus groups discussed better marketing techniques to familiarize the general public with public transportation in their area. Also, they cited flexibility and safety concerns as two of the major reasons for not using transit. Finally, some in the group mentioned a social stigma attached to those riding transit. Metro Transit in Minneapolis surveys the communities employees every two years to determine why they do not use the bus. Those who do not use the bus cite safety concerns and the lack of convenience as the two main culprits. In contrast, those who began using the bus said it was more relaxing and cost less than driving their car to work. Also, those that rode tended to have stops closer to their home and an available shuttle service. Typically, non-users and former users main reason for not using transit is that they have a car available to them.

Policy recommendations are given in Chapter 5 that suggest ways to make transit more attractive to the non-user, such as service improvements, addressing of safety issues, providing of incentives for using transit, and improving the user friendliness of transit systems via technology.

Chapter 6 addresses research collection and analysis methodology and summarizes key issues raised in focus groups and also important questions used in quantitative data collection on surveys.

Chapter 7 is an overall summary of this report.

Declining budgets do not make the task of increasing service to promote non-user ridership any easier. Choice ridership services, such as express service and feeder routes, are usually the first to succumb to budgetary pressures since they are more expensive to operate and do not carry as many passengers as the routes on major thoroughfares. Transit agencies are beginning to announce these types of service cutbacks due to monetary shortfalls. According to a recent Tampa Tribune article by Jim Sloan (2001), Hillsborough County s transit agency is considering decreasing weekend service, eliminating several feeder routes, and/or stopping most nonstop service to curb deficits before appealing to taxpayers for additional funding. Other transit agencies are in similar predicaments. Since transit systems must rely 
upon a larger share of financial commitment by community taxpayers, the need to directly respond to the community s expectations of public transportation has increased, too.

Although community transportation studies depict regional needs and wants, a compilation of the overall commonalities and differences between transit users and non-users can be used as a guide. A common non-user perspective in the suburbs is that a bus is a loser cruiser, meant only for those who cannot afford a personal automobile or are not able to drive. Commuters will only ride if transit is convenient, safe, and affordable. Although urban dwellers tend to have more convenient and frequent service, sometimes metropolitan non-users have personal safety and security concerns. A compilation of nonuser research, commuter demographics, and community transportation surveys are provided in order to gain insight and depict possible solutions for attracting more transit trips. 


\section{CHAPTER 1}

\section{INTRODUCTION}

In the United States, transit is typically considered a means of last resort. The majority of our population appear to value a personal automobile more than the mass transit experience. The American s passion for automobiles compared to transit relates to the perceived convenience of driving. However, transit can offer inviting incentives, including restful riding rather than stressful driving. This report is a compilation of research studies that were conducted to enhance the image of transit in the eyes of the non-transit user. Consequently, its purpose is to serve as a resource to those transit profes sionals who would like to capture the audience that has never been captive. For the purposes of this report, a person that rides transit vehicles will be called a user. In contrast, a person who does not travel via public transportation vehicles will be considered a non-user.

\section{Objectives}

The primary objective of the Transit Non-User Survey: Restful Riding Rather than Stressful Driving project is to present an overview of the success of non-transit use in order to determine useful methods to attract choice riders. The report summarizes information from community transportation studies. Relevant national and international research has been referenced to garner insight into the deterrents to transit usage and the transportation needs of the non-user. In addition, data from the 1995 Nationwide Personal Transportation Survey (NPTS) is analyzed for both the United States and Florida to determine the demographics of the non-riding public. Results of several community attitude surveys about transit are synthesized. Finally, recommendations based on the findings are suggested, including transit operations, transit amenities, marketing, and funding opportunities.

\section{Overview of the Non-user}

The aesthetic exteriors, comfortable interiors, controllable maneuvers, and relative convenience of the automobile appeal to the non-user. In sharp contrast, a loud, odorous, square bus that is operated by another individual and travels along with traffic but with numerous stops apparently does not. Although transit would be a congestion reducer and an environmental protector, it is difficult to attract riders without personal incentives. What must transit operators do to appeal to those who have alternative transportation choices?

\section{The Usual Transit Market}

The national characteristics of transit riders were compiled in 1992 by the American Public Transportation Association (APTA) report, Americans in Transit: A Profile of Public Transit 
Passengers. According to APTA, the majority of transit riders are female, almost one-third are Black, 18 percent are Hispanic, nearly 17 percent are senior citizens, 10 percent are age 18 or under, and 38 percent have family incomes below $\$ 15,000$ (excludes New York City). Moreover, after surveying 136 transit systems of varying size throughout the United States, Linsalata (1992) asserts that, although transit ridership in the United States has increased, the majority of users are female and minorities (i.e., AfricanAmericans, Hispanics, Asians) and are using transit in disproportionate amounts compared to their population shares. Additionally, Linsalata states that transit is an indispensable service for seniors. Finally, Rosenbloom (1998) found that workers with low incomes and no household cars tend to use transit more. Also according to Rosenbloom, immigrants who have been in the United States less than 10 years utilize transit frequently. She also found that riders tend to be young adults (age from seventeen to twenty-nine) and that women utilize transit more often than men. These studies suggest that a typical non-user would be a white, middle-aged man with a household income above $\$ 15,000$.

\section{Non-User Commuters}

During the 1970s American towns with privately-owned transit operations faced difficult decisions. Competition with the automobile had made a lucrative transit business considerably less profitable. The automobile contained the competitive advantage of convenience. Moreover, it allowed people to move further away from the urban core, decreasing the nec essary density of inner cities for a profitable public transportation business. Transit services, such as frequent headways and number of routes, were substantially cut when the profitability of these companies began decreasing. Some communities contemplated public acquisition of these privately-owned bus services in order to gain better transit service for their citizens. In 1975, a community in Wisconsin faced similar conditions. While Milwaukee County considered whether to support the transit system, Thomson et al. (1976) surveyed the community to identify potential transit improvements. The surveys determined characteristics of potential users as well as the potential for service upgrades. Decreasing fare price, increasing reliability, and decreasing wait and travel times were found to be the best enhancements.

A major finding of the study was that transit usage had declined due to the need for an automobile during the workday. In fact, almost one-third (29 percent) of the respondents indicated that a need for the flexibility an automobile affords is the largest barrier to using an improved bus service. Consequently, the authors conclude that since a fixed-route transit service was not economical for these commuters, other flexible transportation services (i.e., demand responsive, improved taxi cab, employee-sponsored services) provided on a pool basis could better minimize dependence on automobile usage. This community decided to acquire the transit service in the hopes that better service would garner more trips from users and appeal to some of those who had stopped using the system.

Similar surveys were conducted in Atlanta, Georgia and Orange County, California. Byrd (1976) 
surveyed Atlanta s residents to determine whether there were significant differences in regard to characteristics, attitudes and perceptions about transit between users and non-users. Fielding et al. (1976) studied non-users mode of choice decisions in Orange County. According to Fielding et al., a non-user s mode of choice decision is affected by several factors, including reliability, time constraints, trip costs, payment method and comfort. Both studies indicated that non-users are more satisfied with driving their personal automobiles than riding public transit. However, Byrd suggests that Atlanta s non-users could be attracted to transit if their perception of convenience was changed through service enhancements. In contrast, Fielding et al. determined that 70 percent of the Orange County respondents indicated an unwillingness to discontinue automobile usage. However, several operational aspects were found to promote transit usage:

" Proximity of a trip s origin and destination;

" Attitudes of bus operators (found to be more important to public image than costly amenities);

" Shopping routes are very important, especially for elderly and youth; and

" Environmental impact campaigns, which link public transit use to smog reduction.

More recent studies of the non-user have researched commute characteristics, service features, and convenience factors. Abdel-Aty et al. (1996) studied the commute characteristics of non-users in San Jose and Sacramento California. They determined two important factors that affect the commuters decisions:

" As the travel time by transit increases, a commuter s likelihood to use transit diminishes.

" Those who commute to multiple work locations are less likely to use the transit mode.

In addition, Mierzejewski and Ball (1990) surveyed non-users in 17 urban areas across the United States (San Francisco, Los Angeles, Phoenix, Denver, Houston, Minneapolis, Madison, Chicago, Kansas City, St. Louis, New York, Boston, Philadelphia, Washington D.C., Atlanta, Tampa and Orlando). They cited that the most substantial reason for commuter non-utilization of public transit is the comparative attractiveness of the automobile. Non-users perceived flexibility and time savings to be the advantages of driving their own cars while public transit was seen by many as having no advantages. However, when non-users were presented with a list of hypothetical improvements to determine whether they would influence their decision to use transit, 50 percent of the respondents claimed that they would switch if the improvements were made. These hypothetical improvements included express fixed-route service, dedicated bus lanes, bus stops near home and work, no transfers, no-wait transfers when transfers are necessary, increased traffic congestion, and personal valet service at transit stop. Finally, when mini-van services with pick-up or discharge points within a block of the destination were suggested, approximately 50 percent of non-users claimed they would utilize such a service. Additionally, Weber et al. (2000) 
found that commuters rated flexibility, convenience, and scheduling as important considerations in shaping workplace-related personal transportation decisions and that single occupancy vehicle users would switch to using other modes if work and home were conveniently linked and accessible. Most importantly, efforts to reduce personal automobile commuting will be met with resistance unless the breach between convenience and flexibility of driving automobiles compared to riding transit can be reduced.

Given that the convenience and flexibility of personal automobiles are superior to transit in its current form, other methods to attract ridership have been studied, too. The Angus Reid Group (1997) studied whether or not appealing to public concerns in Waterloo, Canada, would affect transportation usage patterns. While most respondents agreed that there should be fewer automobile trips due to traffic congestion problems and environmental and health concerns, their choice to switch from automobile drivers to transit users was influenced by better transit service in their area. Moreover, one-in-five (21 percent) said nothing would get them to switch from using their personal automobiles.

However, raising the costs of automobile usage, such as gasoline prices, road tolls, parking costs, and traffic congestion, could increase ridership. Lee et al. (1982) in Oshkosh, asked Wisconsin non-user commuters whether the effect of raising gasoline prices, around $\$ 2.50$ to $\$ 3.00$ per gallon, would change their transportation habits. While 40 percent of them responded that they would continue to drive, they also chose a variety of transportation alternatives, including riding the bus ( 26 percent), carpooling ( 22 percent), walking (20 percent), and bicycling (17 percent). Therefore, a gasoline price increase apparently may cause automobile commuters to consider the use of transportation alternatives.

The Angus Reid Group (1997) found that increasing the costs of automobile usage were unpopular by residents. They gave their subjects a range of methods to lessen automobile usage in order to determine the community s acceptability of certain behavior-altering practices. According to the group s findings, the least acceptable methods, increasing the costs of driving due to road tolls or gas tax (95 percent disagreed) and allowing traffic congestion to increase (88 percent disagreed), were directly related to increasing the costs of automobile usage. In contrast, the most acceptable methods included decreasing the costs of transit as well as increasing the transit service. The highest agreement, 96 percent, was noted for developing a system which better connects the cities and townships within the region. Also, respondents aged 18 to 34 were more likely to consider switching to another form of transportation if a free or subsidized pass was offered.

According to several studies, decreasing the cost of transit by utilizing fare subsidy programs increase ridership by introducing drivers to transit and increasing transit loyalty. In Sweden, Gustafson and Golob (1971) determined that convenience factors (i.e. vehicle arriving when planned, having a seat, no transfer 
trip required, calling without delay, having shelters at pickup, less waiting time and choosing pickup time) were considered more important than fares in determining mode choice. However, research has also found that some non-users could be influenced by fares when acceptable service and pricing structures are offered.

Fujii and Kitamura (2002) gave free one month bus passes to non-users to determine whether the program would unfreeze habitual automobile usage and positively affect the perception of public transport in Kyoto, Japan. Outcomes were positive: the drivers who received this free bus pass used the bus more frequently and their attitudes towards the bus were more positive. Consequently, it was found that the habit of utilizing the automobile decreased after the intervention. Conklin et al. (2002) studied the impact of employer-based annual transit pass programs throughout the United States. They found several features that increased the successfulness of these type of pass programs, most importantly that pricing assumptions must be updated regularly and this because electronic fare payment structures allow for easier monitoring of program effects, including accumulating company-level data. Neighborhood pass programs were found to be less effective than employer-based pass programs.

Oram and Stark (1996) studied the impact of employee deep discount fares, such as multi-ride tickets and commuter check fare subsidies, in order to determine whether they would increase transit loyalty by commuters who were infrequent users. The authors discovered that multi-ride tickets tend to build revenue while monthly passes do not. In addition, employer pass plans, which increased weekly vouchers from $\$ 20$ to $\$ 30$, did not increase the ridership of infrequent users. This suggests that rather than offering larger subsidies, offering vouchers to a greater number of employees would be more productive in raising ridership. Additionally, the authors stated that marketing subsidies to non-users for occasional use is beneficial since the non-user market is huge. They sugge st that it is easier to sell occasional transit use than a full commitment to it.

\section{Bus Schedule Information}

Available and understandable information is necessary to make transit more convenient for those who do not ride often or have never used transit before. Many transit systems rely upon transit pamphlets as their primary marketing tool. However, several studies have found that these tools are difficult to decipher by the general public. When Everett et al. (1977) studied the impact of printed transit schedule features, they observed that there is a high degree of uncertainty and unpredictability in planning a transit trip and that most transit schedules were not effectively marketing the general public. However, they resolved that single-route pamphlets produced in two colors with clearly designated features, such as bus stops, were found to be the most effective. 
Abdel-Aty and Jovanis (1995) cited that easy to understand route maps were one of the most necessary transit information improvements. Hardin (2001) tested the effectiveness of transit maps and schedules by asking individuals to plan routes using Florida transit systems printed bus schedules and city maps. She found that the bus schedules and maps were not adequate providers of information because they were not easy to understand, even with multiple colors. Hardin concluded that many people do not intuitively understand the concept of transit. They do not know how to read a map; do not grasp the concept that there are bus stops between timepoints; cannot estimate time between timepoints; and could not plan a trip based on their necessary time of arrivals.

While printed route maps and schedules are important, technology can be an additional tool to market transit. Transit information systems (TIS) can disseminate information by providing a variety of information on service, including routing, scheduling, transfers, and fares. Consequently, these technologically-advanced information systems are attractive to non-users by providing convenient, current, and understandable information. In fact, when Abdel-Aty et al. (1996) tested whether the availability of advanced information systems that give the traveler detailed information about transit systems would impact the propensity to use transit, they found that over one-third of the non-users surveyed indicated that they would be more likely to consider transit if information was available. Carpoolers were found to be most likely to use transit at least once per week when given accurate information. The authors surmise that this may be due to the fact that, carpoolers already share their trip with others and may carpool to achieve certain objectives (e.g. save money or because the car is not available everyday) that also may be achieved with transit. In addition, Southworth (1996) emphasized that electronic methods of communication, such as websites, should be utilized because computer systems are able to provide individually tailored travel plans based upon the needs of the rider (i.e., multi-lingual, low literacy levels).

Transit agencies that have websites provide benefits beyond printed schedules. Websites provide commuters, the media, and national/international visitors with 24-hour access to information. Additionally, informative websites heighten the visibility and public interest of transit. They can provide information on the benefits of transit, how to take transit, and transportation services that are offered. Horton and Gillig (1997) studied the advantages of a website in relation to transit agencies and commuter assistance programs. According to their research, those who typically use websites have demographics similar to the non-user (i.e., white males in mid- to high- income brackets). Websites could allow transit agencies the opportunity to market to this elusive demographic group. For instance, by answering frequently asked questions (FAQs) and explaining the services offered, websites can alleviate the anxiety of potential transit commuters. Also, websites enhance customer service by providing feedback mechanisms, such as on-line surveys and email addresses, as well as real-time information (i.e. latest traffic information and bus arrival/departure times). Abdel-Aty et al. (1996) researched website 
informational needs, too. The top needs were found to be bus frequency, waiting time at transit stops, transit route map, and operating hours. In contrast, the least important informational needs were walking time to transit stops, park and ride availability, and seat availability. While websites are useful to promote transportation alternatives to the general public by providing a multitude of informational and service benefits, it is important to remember that the user must have internet access. However, computerized information kiosks at major stops and transfer centers can be helpful to all riders. According to Whelan (1988), computerized information centers would provide assurance to those waiting at bus stops. By providing automated vehicle location control (AVLC) technology at major bus stops and transfer centers, changes in service can be immediately updated and displayed for waiting passengers.

\section{Bus Stop Infrastructure}

The amenities found at bus stops should be used to attract ridership. Bus stops need to be accessible, protect riders from the elements, provide important information, and promote a safe environment. Evans et al. (1997) addressed these issues by evaluating sidewalks, street crossings, transit amenities, and proximity of destinations for pedestrian accessibility to transit. They found that transit use at any particular stop was affected by the proximity of potential origins and destinations as well as road infrastructure. Unsafe roadway conditions appeared to be hostile to pedestrians, lessening the likelihood that transit would be utilized. Negatively perceived roadway factors were determined in this study. These included street crossings with wide facilities, free-flowing or multiple lanes, and streets with no curbs, shoulders, and/or sidewalks.

The public s preferences for bus stop information was studied by Bakr and Robinson (1978). They surveyed and analyzed the relationships between bus stop information and a commuter s demographic characteristics, trip purpose, and transfer practices. The following was found:

" The higher the level of education, the less need for bus stop sign information;

" The value of sign information increases with age;

" African-Americans rate sign information of greater importance;

" American Indians rate sign information of least importance; and

" Females gave higher importance ratings to route number, type of service, hours of service, and route schedule information than their male counterparts.

Also, Bakr and Robinson (1978) found that a commuter s trip purpose affected the type of bus stop information requested. For instance, bus stop sign information was rated highest among those who use the bus for multiple purposes or for shopping. In contrast, bus stop sign information was rated lowest by those who utilize the bus for school. Finally, the results indicated that commuters who transferred ranked elements of bus stop sign information higher than those who did not transfer. They conclude that the most important bus sign information was determined to be route number, hours of service, waiting time 
for the bus, route name and schedule, type of service, and route map.

\section{Safety Issues and Perceptions}

Loukaitou-Sideris and Liggett (2000) studied how the physical environment at and near transit bus stops influences perceived and actual passenger safety. They surveyed riders waiting at the ten most dangerous bus stops in Los Angeles. One-third of the respondents had been a victim of crime on the bus or at the bus stop within the previous five years. Most of the crimes occurred in isolated situations where there were numerous hiding places and escape paths. In order to determine whether the physical and social environment influences bus stops safety, Loukaitou-Sideris and Liggett studied an additional sixty high and low-crime bus stops in downtown Los Angeles, examining the urban-form characteristics of the surrounding area, the bus stop characteristics, and the street characteristics. Bus stops placed near alleys, mid-block passages, multi-family housing, liquor stores, buildings marked by graffiti, and litter tended to be more crime prone.

In contrast, Reed et al. (1999) discovered that transit patrons in Michigan generally feel safe when using transit. However, they determined that there is a higher perceived level of possible crime the longer the wait at the bus stop. Consequently, the transit riding public s most desired security improvements were found to be emergency phones and increased lighting at bus stops. Since non-users tend to perceive transit safety more negatively than users, it was suggested that adding telephones and additional light could possibly attract non-users, too.

The perception of transit impacts usage, especially by those who are not familiar with riding the bus. In Montgomery, Alabama, Reese et al. (1980) conducted a survey of transit perceptions and their effect on travel behavior. According to those surveyed, social acceptability concerns and perceived safety (both waiting for and riding on the bus) were more important than perceptions of comfort when deciding on whether or not to ride transit. Social acceptability concerns stemmed from class issues rather than race issues. Also, trip type affected the perceived acceptability of taking transit. Although non-users considered the car to be the most appropriate mode for all types of trips, going out for the evening was rated as not appropriate for using the bus by both the users and non-users. If non-users hypothetically did not have access to an automobile, their second choice was bus for all trips except for those to the airport (taxi) and school (carpool).

Researchers agree that users have a better, more accurate perception of transit-related safety than nonusers. Non-users tend to perceive transit as being less safe than it is in actuality. According to Ingalls et al. (1994), in Greensboro, North Carolina, perceptions of safety and security deter non-users from using mass transit. In fact, non-user residents were found to be two to five times more concerned about personal safety on buses than riders. Furthermore, Benjamin and Hartgen (1994) compared the public s 
perception of crime to the actual incidence of crimes on buses in Greensboro, North Carolina. Although one-half of the residents surveyed perceived crime on transit to be a problem, the public fear was found to be invalid since the true level of transit-related crime (from police reports) was actually lower than the perceived level of crime. Again, experience was noted to be a determinant in a person s perception of personal safety in transit since non-users were more concerned about personal safety on buses than users or bus drivers.

\section{Accessibility to Activity Centers}

Although introducing non-users to the bus is difficult due to their perceptions of convenience, social status, and safety, providing convenient service to places of interest would attract some choice riders as well as visitors. Recently, Hardin (2001) studied access to Florida s activity centers, such as airports, medical centers, shopping centers, business/government centers, recreational facilities, and educational centers to determine how well transit served them. According to her research, most of the activity centers are accessible by transit, albeit not at the most convenient or necessary times. For instance, activity centers that are open and may need to be used during late at night and early in the morning (i.e., airports, medical, shopping, and education) operate past the transit s typical span of service. Moreover, due to the fact that most transit service is limited or not available during Sunday, activity centers that are operated on Sunday contain limited accessibility by transit. Of all the activity centers, airports have the least service and business/government centers have the highest level of service. Since the service at airports have a weekday average of 1.45 buses per activity center operating hour and a Saturday average of 1.01 buses per activity center operating hour, she suggested that transit service to airports is not meant to accommodate airport workers or visitors. Additionally, recreational facilities received a lower level of service during the weekends, even though this category is more likely to be used by residents and visitors during the weekends. Finally, Hardin reported that although educational centers receive a large level of transit support during the weekdays, they do not receive much on the weekends, even though Saturday classes are held at most of the institutions. Consequently, residents who would like to take classes during the weekend would probably not be able to use transit. By enhancing bus service based upon activity center hours of operation and usage patterns, transit could potentially gain choice riders, including students, airport, hospital, and shopping center employees, local resident weekenders, and visitors.

Additional benefits of convenient transit accessibility to employers are stimulating local economies and providing job access to the transportation disadvantaged. Linsalata (1992) reported that local economic environments are stimulated by the presence of transit since 70 percent of transit use was found to be related to business and/or educational activities, while work trips accounted for over half of all trips made using public transit in the United States. Rosenbloom (1998) determined that workers with mobility or work limitations are more likely to use transit for commuting to work. Therefore, as Cervero (1997) suggested, access to employment via transit is important and transportation planning models should 
include job accessibility measures to assist transportation planners in their tasks of making destinations easier to reach. 


\section{CHAPTER 2}

\section{DEMOGRAPHICS OF THE NON-USER PUBLIC}

Current Census 2000 transit data is relatively limited and will not be available until Fall 2002. The most comprehensive and recent data available is from the 1995 Nationwide Personal Transportation Survey (NPTS) database. NPTS focuses on the daily, local trips of U.S. citizens. From 2000 to 2001, the National Household Travel Survey (NHTS) was conducted by the U.S. Department of Transp ortation in an effort to provide the full continuum of travel, and provide national estimates of trips and miles by travel mode, purpose, and other vital travel information. The NHTS combines the Federal Highway Administration s NPTS and the Bureau of Transportation Statistic s American Travel Survey (ATS), the most recent source of national transportation trips, into a comprehensive data gathering tool.

Unfortunately, the results of the NHTS can not be utilized since the database will not be released until late 2002.

The evaluation of NPTS data for users and non-users first warrants an explanation of the crosstabular strategies employed and caveats encountered. Four groups were established using the NPTS data:

" Transit Available/Usual Mode Not Transit;

" Transit Available/Usual Mode Transit;

" Transit Not Available; and

" Other.

The groups that include work-related trip non-users are transit available/usual mode not transit, transit not available, and other. Children, missing answers, and non-workers are included in the other category. In contrast, the transit available/usual mode transit category contains users. Included transit modes are AMTRAK, bus, subway or elevated rail, streetcar, and/or commuter train modes. Although all of these categories were delineated from the available NPTS codes and variables to create the most current information comparisons between transit users and non-users, there are limitations from utilizing only work-trip data.

By using NPTS data to represent actual transit rider behavior, there are a couple of drawbacks that are encountered. For instance, if a respondent uses transit for trips other than work, (s)he is essentially still categorized as a non-user since only work trips are encountered herein. As such children, retired senior citizens, and the unemployed are eliminated from the transit rider category, as well, even though they typically use transit for other types of trips. Moreover, sometimes transit service was not available to the surveyed respondent. Consequently, they are not users of transit. The data are sorted to reflect the difference between non-users who have transit available in their communities and non-users who live in a 
communities that do not provide transit. Only those who have transit available to them in the United States are included in this report.

Additionally, in order to gain insight into Florida s user and non-user demographics, the NPTS data that contain responses from Floridians have been analyzed and evaluated. Since Florida s data sample is somewhat limited, some estimates may vary widely from these values. Hence, care is needed when surmising the typical demographic characteristics.

For the convenience of the reader, the actual sample sizes in each category can be found in the NPTS crosstabulation and frequency tables in Appendix A. The data are arranged into five separate demographic categories (age, gender, automobile ownership, income, and ethnicity). It is hoped that by understanding the demographic differences between transit users and non-users, a campaign to increase transit ridership will be more persuasive by targeting relevant markets with the greatest potential for overall impact.

Age:

Transit ridership is delineated via eight age-based categories. Table A depicts the percent of worker users and non-users by age in the United States and Florida. In United States, as well as Florida, most workers do not use transit as a commute option (approximately 90 percent do not use transit). The age groups that tend to have more full-time workers (after high school graduation and before retirement) seem to have the highest propensity for transit use. For instance, the 20-29 and 30-39 age groups have the most workrelated users. In contrast, the workers of the 16-19 age group category and the age groups above 60 have the lowest proportion of users in relation to their respective age groups population size. 
Table A

Workers by Age Where Transit is Available

\begin{tabular}{|c|rr||rr|rr|rr|}
\cline { 2 - 9 } \multicolumn{1}{c|}{} & \multicolumn{2}{c|}{ US Transit Non-user } & \multicolumn{2}{c|}{ US Transit User } & \multicolumn{2}{|c|}{ FL Transit Non-user } & \multicolumn{2}{|c|}{ FL Transit User } \\
\hline AGE & Weighted & Percent & Weighted & Percent & Weighted & Percent & Weighted & Percent \\
& Sample & & Sample & & Sample & & Sample & \\
$5-15$ & $\mathrm{n} / \mathrm{a}$ & $\mathrm{n} / \mathrm{a}$ & $\mathrm{n} / \mathrm{a}$ & $\mathrm{n} / \mathrm{a}$ & $\mathrm{n} / \mathrm{a}$ & $\mathrm{n} / \mathrm{a}$ & $\mathrm{n} / \mathrm{a}$ & $\mathrm{n} / \mathrm{a}$ \\
$16-19$ & $3,788,824$ & $5.69 \%$ & 349,962 & $4.89 \%$ & 210,588 & $6.48 \%$ & 3,177 & $2.92 \%$ \\
$20-29$ & $15,699,276$ & $23.60 \%$ & $1,847,037$ & $25.83 \%$ & 703,399 & $21.64 \%$ & 43,714 & $40.12 \%$ \\
$30-39$ & $19,641,081$ & $29.52 \%$ & $2,211,510$ & $30.92 \%$ & 975,700 & $30.01 \%$ & 45,245 & $41.53 \%$ \\
$40-49$ & $15,526,298$ & $23.34 \%$ & $1,656,359$ & $23.16 \%$ & 807,845 & $24.85 \%$ & 10,890 & $9.99 \%$ \\
$50-59$ & $8,079,970$ & $12.14 \%$ & 824,413 & $11.53 \%$ & 350,356 & $10.78 \%$ & 2,766 & $2.54 \%$ \\
$60-64$ & $2,131,974$ & $3.20 \%$ & 131,036 & $1.83 \%$ & 95,922 & $2.95 \%$ & 3,160 & $2.90 \%$ \\
$65+$ & $1,667,782$ & $2.51 \%$ & 131,616 & $1.84 \%$ & 107,082 & & 0 & $0.00 \%$ \\
\hline Total & $66,535,205$ & $100.00 \%$ & $7,151,933$ & $100.00 \%$ & $3,250,892$ & $100.00 \%$ & 108,952 & $100.00 \%$ \\
\hline
\end{tabular}

\section{Gender:}

Females have a higher propensity to use transit than males. According to the 2000 Population Data Sheet by the Population Reference Bureau, 46 percent of the United States worker population are female. In the United States, although the American labor force has more males than females, males use transit less for work trips. Not surprisingly, the Florida non-user is also more likely to be male. In Florida, twice as many women use transit as men. Women may be more transit dependent since they usually have less disposable income, especially if they are the head of household and responsible for raising and providing for children. Households with one vehicle and two heads of household may also cause disparity between the sexes. If the main income provider, usually male, needs to commute by car, the secondary provider may need to utilize transit for work trips. Finally, compared to males, women, especially those with children, may choose jobs that are closer to home. Hence, the transit option would be more convenient for women who have shorter work trips. 
Table B

\section{Workers by Gender Where Transit is Available}

\begin{tabular}{|c|c|c|c|c|c|c|c|c|}
\hline \multirow[b]{2}{*}{ GENDER } & \multicolumn{2}{|c|}{ US Transit Non-user } & \multicolumn{2}{|c|}{ US Transit User } & \multicolumn{2}{|c|}{ FL Transit Non-user } & \multicolumn{2}{|c|}{ FL Transit User } \\
\hline & $\begin{array}{l}\text { Weighted } \\
\text { Sample }\end{array}$ & Percent & $\begin{array}{l}\text { Weighted } \\
\text { Sample }\end{array}$ & Percent & $\begin{array}{l}\text { Weighted } \\
\text { Sample }\end{array}$ & Percent & $\begin{array}{l}\text { Weighted } \\
\text { Sample }\end{array}$ & Percent \\
\hline Male & $35,725,074$ & $53.69 \%$ & $3,341,322$ & $46.72 \%$ & $1,773,450$ & $54.55 \%$ & 40,869 & $37.51 \%$ \\
\hline Female & $30,810,132$ & $46.31 \%$ & $3,810,611$ & $53.28 \%$ & $1,477,443$ & $45.45 \%$ & 68,084 & $62.49 \%$ \\
\hline Total & $66,535,206$ & $100.00 \%$ & $7,151,933$ & $100.00 \%$ & $3,250,893$ & $100.00 \%$ & 108,953 & $100.00 \%$ \\
\hline
\end{tabular}

\section{Automobile Ownership:}

As automobile ownership increases, transit ridership decreases. Approximately 95 percent of Americans who work have a household automobile. Of those who own an automobile, only eight percent utilize transit for work trips. For comparison, 63 percent of those who do not have an automobile in their household ride transit to work. Similar to national results, the Florida non-user usually owns a car. Perhaps due to the mild climate, Floridians frequently can walk or ride their bikes to work if they do not have a car. Finally, according to the NPTS data, Floridian households with two automobiles are almost always non-user commuters.

\section{Table C}

\section{Workers by Automobile Ownership Where Transit is Available}

\begin{tabular}{|c|c|c|c|c|c|c|c|c|}
\hline & \multicolumn{2}{|c|}{ US Transit Non-user } & \multicolumn{2}{|c|}{ US Transit User } & \multicolumn{2}{|c|}{ FL Transit Non-user } & \multicolumn{2}{|c|}{ FL Transit User } \\
\hline CAR & $\begin{array}{l}\text { Weighted } \\
\text { Sample }\end{array}$ & Percent & $\begin{array}{l}\text { Weighted } \\
\text { Sample }\end{array}$ & Percent & $\begin{array}{l}\text { Weighted } \\
\text { Sample }\end{array}$ & Percent & $\begin{array}{l}\text { Weighted } \\
\text { Sample }\end{array}$ & Percent \\
\hline 0 & $1,333,301$ & $2.00 \%$ & $2,236,799$ & $31.28 \%$ & 32,645 & $1.01 \%$ & 21,198 & $19.54 \%$ \\
\hline 1 & $15,520,066$ & $23.33 \%$ & $2,809,259$ & $39.28 \%$ & 599,588 & $18.44 \%$ & 44,772 & $41.26 \%$ \\
\hline 2 & $31,566,766$ & $47.44 \%$ & $1,545,587$ & $21.61 \%$ & $1,769,804$ & $54.44 \%$ & 23,258 & $21.44 \%$ \\
\hline $3+$ & $18,115,073$ & $27.23 \%$ & 560,288 & $7.83 \%$ & 848,857 & $26.11 \%$ & 19,275 & $17.76 \%$ \\
\hline Total & $66,535,206$ & $100.00 \%$ & $7,151,933$ & $100.00 \%$ & $3,250,894$ & $100.00 \%$ & 108,953 & $100.00 \%$ \\
\hline
\end{tabular}

\section{Income:}

Generally, as income increases, transit ridership decreases. Table D depicts that Americans who are impoverished (earn less than $\$ 15,000$ annually) ride transit more than persons in any other income level. Hence, non-users appear to be primarily middle class. According to NPTS data, Americans earning over $\$ 60,000$ annually utilize transit more than the middle class, albeit at a much lower percentage than those residing in poverty. This phenomenon is more than likely due to the fact that those who live in large 
cities, such as Boston and New York City, typically earn higher comparative incomes and are more likely to use transit since it is more convenient due to parking costs and/or shortages, shorter transit headways, and multiple available modes. In comparison, the Florida non-user segment encompasses all but those in poverty income brackets. For example, none of the sampled Florida participants who earn over $\$ 60,000$ commute by transit. Moreover, over 97 percent of Florida s middle class do not use transit for work trips.

\section{Table D}

\section{Workers by Income Where Transit is Available}

\begin{tabular}{|c|c|c|c|c|c|c|c|c|}
\hline \multirow[b]{2}{*}{ INCOME } & \multicolumn{2}{|c|}{ US Transit Non-User } & \multicolumn{2}{|c|}{ US Transit User } & \multicolumn{2}{|c|}{ FL Transit Non-user } & \multicolumn{2}{|c|}{ FL Transit User } \\
\hline & $\begin{array}{l}\text { Weighted } \\
\text { Sample }\end{array}$ & Percent & $\begin{array}{l}\text { Weighted } \\
\text { Sample }\end{array}$ & Percent & $\begin{array}{l}\text { Weighted } \\
\text { Sample }\end{array}$ & Percent & $\begin{array}{l}\text { Weighted } \\
\text { Samp le }\end{array}$ & Percent \\
\hline $\begin{array}{l}\$ 0,000- \\
\$ 14,999\end{array}$ & $4,129,945$ & $6.21 \%$ & 832,708 & $11.64 \%$ & 238,076 & $7.32 \%$ & 43,308 & $39.75 \%$ \\
\hline $\begin{array}{c}\$ 15,000- \\
\$ 29,999\end{array}$ & $12,451,429$ & $18.72 \%$ & $1,682,793$ & $23.53 \%$ & 568,249 & $17.48 \%$ & 16,469 & $15.12 \%$ \\
\hline $\begin{array}{c}\$ 30,000- \\
\$ 59,999\end{array}$ & $24,879,167$ & $37.39 \%$ & $1,970,382$ & $27.55 \%$ & $1,332,204$ & $40.98 \%$ & 16,530 & $15.17 \%$ \\
\hline$\$ 60,000+$ & $14,991,256$ & $22.53 \%$ & $1,500,840$ & $20.99 \%$ & 532,248 & $16.37 \%$ & 0 & $0.00 \%$ \\
\hline $\begin{array}{l}\text { Non- } \\
\text { reporting }\end{array}$ & $10,083,409$ & $15.15 \%$ & $1,165,210$ & $16.29 \%$ & 580,116 & $17.85 \%$ & 32,645 & $29.96 \%$ \\
\hline Total & $66,535,206$ & $100.00 \%$ & $7,151,933$ & $100.00 \%$ & $3,250,893$ & $100.00 \%$ & 108,952 & $100.00 \%$ \\
\hline
\end{tabular}

\section{Ethnicity:}

Transit ridership is delineated by ethnicity in Table E. According to NPTS data, almost 94 percent of Whites residing in the United States are non-user commuters. In contrast, over 22 percent of the Black population in the United States utilizes transit for work trips. As an ethnic group, a larger percentage of Blacks use transit for work trips than Whites, Hispanics, Asians, and other ethnic groups/races.

Floridians have slightly different ethnic correlations than their fellow Americans. Ninety-nine percent of Floridian Whites indicate being non-user commuters. Also, in Florida, Hispanics utilize transit the most in absolute terms while Asians have the largest percentage of transit ridership usage for work trips. 
Table E

Workers by Ethnicity Where Transit is Available

\begin{tabular}{|c|c|c|c|c|c|c|c|c|}
\hline \multirow[b]{2}{*}{ ETHNICITY } & \multicolumn{2}{|c|}{$\begin{array}{c}\text { US Transit Non- } \\
\text { user }\end{array}$} & \multicolumn{2}{|c|}{ US Transit User } & \multicolumn{2}{|c|}{ FL Transit Non-user } & \multicolumn{2}{|c|}{ FL Transit User } \\
\hline & $\begin{array}{l}\text { Weighted } \\
\text { Sample }\end{array}$ & Percent & $\begin{array}{l}\text { Weighted } \\
\text { Sample }\end{array}$ & Percent & $\begin{array}{l}\text { Weighted } \\
\text { Sample }\end{array}$ & Percent & $\begin{array}{l}\text { Weighted } \\
\text { Sample }\end{array}$ & Percent \\
\hline Hispanic & $7,448,177$ & $11.19 \%$ & $1,146,508$ & $16.03 \%$ & 553,837 & $17.04 \%$ & 39,222 & $36.00 \%$ \\
\hline White & $47,143,460$ & $70.85 \%$ & $3,088,186$ & $43.18 \%$ & $2,189,618$ & $67.35 \%$ & 20,765 & $19.06 \%$ \\
\hline Black & $7,977,184$ & $11.99 \%$ & $2,357,980$ & $32.97 \%$ & 404,492 & $12.44 \%$ & 33,147 & $30.42 \%$ \\
\hline Asian & $1,948,187$ & $2.93 \%$ & 272,775 & $3.81 \%$ & 47,859 & $1.47 \%$ & 4,892 & $4.49 \%$ \\
\hline Other & $1,530,011$ & $2.30 \%$ & 214,483 & $3.00 \%$ & 43,387 & $1.33 \%$ & 10,926 & $10.03 \%$ \\
\hline Non-reporting & 488,187 & $0.74 \%$ & 72,001 & $1.01 \%$ & 11,700 & & 0 & $0.00 \%$ \\
\hline Total & $66,535,206$ & $100.00 \%$ & $7,151,933$ & $100.00 \%$ & $3,250,893$ & $\begin{array}{l}0.37 \% \\
100.00 \%\end{array}$ & 108,952 & $100.00 \%$ \\
\hline
\end{tabular}

\section{SUMMARY OF DEMOGRAPHICS}

Although transit is available for most U.S. citizens, only a few utilize transit modes for work trips according to the 1995 NPTS. Florida s non-user demographics mostly reflect those of the United States. Nationwide, transit is not available for about 17 percent of the working population $(41,809,664$ U.S. citizens). Transit is not available for about 11 percent of Florida s working population $(1,189,424$ Floridians). Where transit is available, less than three percent of the national working population utilizes it for work trips. Consequently, potential choice transit work trip users are nearly 28 percent of the population $(66,535,205$ U.S. citizens). In contrast, only one percent of Florida s population uses transit for work trips where it is available (108,952 Floridians). Nearly one-third of Florida s citizens use another form of transportation to commute to work (3,250,892 Floridians).

Striving to market even a small percentage of working commuters to ride transit rather than drive could potentially provide a large increase in transit annual ridership. These working citizens encompass a large, viable target market for transit: they need transportation to get to work, already have transit in their community, and could become loyal riders that take approximately 10 trips a week. Using the figures from this analysis, for example, if transit was able to persuade 1 percent of the non-user commuters to ride the bus or rail for work purposes, 665,352 American citizens would potentially use transit 5 days a week for at least 2 trips a day, revealing a potential 6,653,520-trip increase in weekly transit ridership. Annually, transit ridership could relatively increase by over 300 million trips. Hence, if the transit industry decided to target just three percent of the commuters who do not utilize transit, transit trips could 
increase substantially. Similarly, if Florida transit agencies could persuade three percent of its commuters (97,527 Floridians according to the 1995 NPTS) to travel by bus or rail, transit ridership could potentially increase by millions of trips annually.

By determining the demographics of users and non-users, transit service can be enhanced to fit targeted markets. Commuters who do not ride transit are potential transit users. Providing convenient service to them, as well as other amenities or incentives, may persuade them to choose riding transit rather than driving an automobile to and from work. NPTS data yield the characteristics of the working public s travel preferences. 


\section{CHAPTER 3}

\section{FLORIDA COMMUNITY PUBLIC TRANSPORTATION SURVEYS}

This section will analyze the opinions and expectations of transit communities in Florida. The community survey results that are provided in this report encompass a wide range of demographic and transit service characteristics. For instance, a large community, such as Dade County, has access to a variety of transit resources whereas a small community, such as the city of Winter Haven, has less access to different public transportation modes and frequent transit service. Overall, community survey reports and data were collected from nine transit communities within the state of Florida:

" Broward County Transit (BCT): Transit Needs Study, phone survey, 1996

" Hillsborough County Metropolitan Planning Organization-Hillsborough Area Transit (HART): Survey on Long Range Transportation Goals, phone survey, 2001

" Jacksonville Transportation Authority (JTA): General Public Survey, phone survey, 1999

" $\quad$ Lynx Transit (LYNX): Community-Wide Survey, phone survey, 1998

" Metro Dade County-Metro Dade Transit (MDT): Transportation Tracking Survey, phone survey, 1997

" Palm Beach County (PALM TRAN): General Public Survey, phone survey, 1999

" Pinellas Suncoast Transit Authority (PSTA): Riders, Potential Riders and General Public Transit Survey, phone survey, 1998

" Tallahassee Transit (TALTRAN): Community Attitude Survey, mailbox survey, 2000

" Winter Haven Area Transit(WHAT): Community Attitude Survey, personal survey, 2001

Appendix B contains the survey instruments used by each agency. Although the agencies that funded the surveying are either the transit agencies themselves, the MPO responsible for the transportation needs of the community, or county affiliates, this report will refer to the surveyors by their transit acronym. For example, Metro Dade County funded the Transportation Tracking Survey that contained some Metro Dade Transit (MDT) questions. When the report refers to this survey, MDT will be used.

Concatenating these data sets is problematic. Since the surveys were developed for a variety of needs, many of the questions are not standardized. For instance, the types of questions in each survey depended upon whether the purpose was to garner community support for transit, enhanc e existing public transportation operations, and/or determine the importance of transit compared to other transportation needs. Moreover, some of the surveys dedicated a couple of questions to transit while others were purely transit-oriented. Finally, system size played a role in the length and breadth of a survey. The smaller, newer systems typically asked questions related to a common theme, such as community fiscal support. In contrast, the larger, more established systems tended to ask questions in order to study a variety of 
topics, but particularly focused on improving operations. Hence, the data collected from these surveys are compared and contrasted according to subject matter. The topics that are presented herein include community image, service improvements to entice ridership, and funding sources.

\section{Community Image}

The ratings of a public transportation system by its residents measure the perception as to whether the provided transit service fulfills its community role. Since many of the respondents are non-users, this measure is not meant to provide information about the quality of the service. Instead, it is meant to portray a general rating of the system from the public s vantage point. Without direct knowledge of the exact characteristics of the service, the general public s ratings could be based upon many factors. Some factors that may influence perceptions are media coverage, marketing, personal experience, and demographic characteristics. The ratings of a public transportation system are important performance measures since they measure whether current residents believe that public transportation is fulfilling its major roles. As a rule, the more positively a transit system is perceived, the greater the propensity is for residents to try transit.

Three communities (Hillsborough County, the city of Jacksonville, and the city of Tallahassee) asked respondents, How good a job has public transit done at providing ways to get around the community? In Table F, the responses are quantified on a scale from one (poor) to five (excellent). Although each of the transit systems and their respective communities are unique, the results to this perception question were relatively similar. The average response was a three, indicating that transit service is perceived to be adequate. Also, those with stronger viewpoints tend to fall on both sides of the spectrum. A chart of these results can be found in Figure 1 of the next section.

\section{Table F}




\section{How good a job has public transit done at providing ways to get}

around the community?

\begin{tabular}{|c|r|r|r|r|r|r|}
\cline { 2 - 7 } \multicolumn{1}{c|}{} & \multicolumn{1}{c|}{ Excellent } & Good & Adequate & \multicolumn{1}{c|}{ Fair } & \multicolumn{1}{c|}{ Poor } & \multicolumn{1}{c|}{$\begin{array}{c}\text { Average } \\
\text { Score }\end{array}$} \\
\hline HART** & $2.0 \%$ & $32.3 \%$ & $43.5 \%$ & $14.8 \%$ & $7.5 \%$ & 2.91 \\
JTA* & $7.6 \%$ & $25.0 \%$ & $28.3 \%$ & $16.1 \%$ & $7.4 \%$ & 2.63 \\
TALTRAN & $7.9 \%$ & $22.2 \%$ & $40.8 \%$ & $17.4 \%$ & $11.7 \%$ & 2.97 \\
\hline
\end{tabular}

* For the JTA survey, 15.6 percent of respondents didn t know or refused to answer this question.

** These were the numbers presented in the HARTLINE survey. They add up to $100.1 \%$.

In two other related survey questions, Jacksonville respondents concur that transit is a vital service for their community. For instance, Jacksonville residents were asked whether the need for transit in their community has changed. Its survey question states, to what extent do you feel the need for public transit service in Jacksonville has changed in the last two years? More than half of the respondents (58 percent) perceived that the need for transit has increased. Whereas, 21 percent said that needs were basically the same and 5 percent stated that the need had declined. Jacksonville survey respondents were also asked to quantify whether, public transportation is an important part of solving our local transportation problems. Over 80 percent of the Jacksonville respondents (52.6 percent strongly agreed and 32.0 percent somewhat agreed) felt public transportation plays an integral role in helping to solve local transportation problems. While most agree that transit is important for Jacksonville, JTA could do a better job at providing ways to get around the community. Additional connections to make it easier for residents to go where they want to go may improve JTA s scores in Table F.

Additionally, LYNX surveyed its community (primarily Orlando) on whether transit service has improved and if transit is beneficial to their community. When asked to agree or disagree with the statement, Bus service has improved significantly over the last few years, more than half of the respondents ( 29 percent completely agreed and 26 percent somewhat agreed) agreed. Also, 18 percent were neutral, 2 percent somewhat disagreed, 4 percent completely disagreed, and 22 percent did not know. Respondents were also asked, has the need for mass transportation in and around Orlando increased in the past few years? Similar to other transit communities in Florida, most Orlando respondents ( 70 percent) believe that the need for transit in their community has increased. For comparison, 12 percent said it stayed the same, 1 percent said it declined, and 17 percent did not know. Additionally, over 60 percent (36 percent completely agree and 30 percent somewhat agree) agree that, LYNX really improves the quality of life in the area. In contrast, 22 percent were neutral, 2 percent somewhat disagreed, 2 percent completely disagreed, and 8 percent did not know. Hence, transit $\mathrm{s}$ benefits are appealing to a majority of respondents and LYNX enjoys a good perception of its need within the community. Yet, over one-third of the respondents ( 25 percent completely agree and 9 percent 
somewhat agree) indicated that they were not sure how I would ever use LYNX. (In addition, 12 percent were neutral, 15 percent somewhat disagreed, and 36 percent completely disagreed, and 3 percent did not know.) Therefore, increasing the usability of LYNX is needed. Perhaps teaching the public how to use the bus (i.e., the cost, the destinations, schedule availability, service span, bicycle racks) through informative marketing campaigns could possibly attract new riders. Also, providing more buses in their area and expanding routes were suggested by respondents as items that would make taking the bus more attractive (see Figure 6).

There is support for transit in the Palm Beach community, too. For instance, when Palm Beach residents were asked whether public transit is an important service for Palm Beach County, an overwhelming majority (61 percent strongly agree and 28 percent somewhat agree) agreed. For comparison, four percent were neutral, three percent somewhat disagreed, and two percent did not know/refused to answer. While many believe that Palm Tran is very important to Palm Beach county, Palm Tran s service is perceived to be adequate. When asked, overall, how would you rate the public transit system in Palm Beach County? 46 percent of the respondents cited an adequate rating, whereas 8 percent rated it very good, 25 percent good, 14 percent poor, and 8 percent very poor. Figure 9 suggests that service enhancements, such as stops closer to home and work, better route information, and better schedule information, may improve overall system ratings and entice more ridership for Palm Tran.

The image statement, public transportation is just for those without an automobile, was posed to Hillsborough County (HART) and Orlando (LYNX) residents. Table G depicts that a majority of the respondents from both communities disagreed with this statement. In fact, 58 percent of the Hillsborough County residents surveyed indicated that they either somewhat disagree or strongly disagree with the statement. Moreover, 58 percent of those surveyed in the city of Orlando either somewhat disagreed or strongly disagreed with this statement. Although the majority of respondents perceive transit to be for everybody-those who have automobiles as well as those who do not, approximately one-third of the respondents did not. Some feel that transit is meant to be a social service to those who either cannot afford a car (i.e., low income families) or are not capable of driving (i.e., disabled and/or elderly). A graphical representation of these results can be found in Figure 2 in the next section.

\section{Table G}

Page 29 of 61 pages 


\section{Public Transportation is Just for Those Who}

Cannot Afford a Car.

\begin{tabular}{|c|r|r|r|r|r|r|}
\cline { 2 - 6 } \multicolumn{1}{c|}{} & \multicolumn{1}{c|}{$\begin{array}{c}\text { Strongly } \\
\text { Agree }\end{array}$} & $\begin{array}{c}\text { Somewhat } \\
\text { Agree }\end{array}$ & $\begin{array}{c}\text { Neither } \\
\text { Agree Nor } \\
\text { Disagree }\end{array}$ & $\begin{array}{c}\text { Somewhat } \\
\text { Disagree }\end{array}$ & $\begin{array}{c}\text { Strongly } \\
\text { Disagree }\end{array}$ & $\begin{array}{c}\text { Undecided } \\
\text { or Refused }\end{array}$ \\
\hline HART & $14 \%$ & $18 \%$ & $10 \%$ & $32 \%$ & $26 \%$ & N/A \\
LYNX & $16 \%$ & $11 \%$ & $15 \%$ & $15 \%$ & $43 \%$ & $0 \%$ \\
\hline
\end{tabular}

Respondents from four Florida communities were asked whether an effective public transportation system is important for their local economy. Table $\mathrm{H}$ indicates approximately 80 percent of the surveyed individuals agree that public transportation helps their local economy. This suggests a high level of general support for the role of public transportation as a supporter of the local economy. Figure 3 in the next section shows a graphical representation of the results shown in Table H. 


\section{Table H}

\section{An Effective Public Transportation System}

is Important for the Local Economy.

\begin{tabular}{|c|r|r|r|r|r|r|}
\cline { 2 - 7 } \multicolumn{1}{c|}{} & \multicolumn{1}{c|}{$\begin{array}{c}\text { Strongly } \\
\text { Agree }\end{array}$} & $\begin{array}{c}\text { Somewhat } \\
\text { Agree }\end{array}$ & $\begin{array}{c}\text { Neither } \\
\text { Agree Nor } \\
\text { Disagree }\end{array}$ & $\begin{array}{c}\text { Somewhat } \\
\text { Disagree }\end{array}$ & $\begin{array}{c}\text { Strongly } \\
\text { Disagree }\end{array}$ & $\begin{array}{c}\text { Undecided or } \\
\text { Refused }\end{array}$ \\
\hline HART & $43.0 \%$ & $41.5 \%$ & $8.9 \%$ & $4.4 \%$ & $2.2 \%$ & N/A \\
JTA & $61.0 \%$ & $28.0 \%$ & $3.0 \%$ & $3.0 \%$ & $3.0 \%$ & $2.0 \%$ \\
LYNX & $60.0 \%$ & $20.0 \%$ & $15.0 \%$ & $1.0 \%$ & $2.0 \%$ & $2.0 \%$ \\
PalmTran & $55.0 \%$ & $29.0 \%$ & $5.0 \%$ & $6.0 \%$ & $4.0 \%$ & $1.0 \%$ \\
\hline
\end{tabular}

Finally, the PalmTran report included a interesting finding that came from correlations between ratings of the public transportation system, tax measure support, agreement in importance of transit, and the likelihood of riding the bus. Those who rated transit favorably and who supported tax funding were expected to be more likely to say that they would ride the bus. However, in the case of PalmTran s study, these correlations were found to be low, indicating that the variations in intention to use transit could not be explained. We can draw the conclusion from these correlations that some of those people who support transit may not be those who intend to ride it.

\section{Service Improvements to Entice Ridership}

Most of the communities asked their residents to determine which potential service improvements would persuade them to use transit in the future. In fact, Taltran and WHAT were the only agencies that did not ask for this type of information. While WHAT s survey was short and primarily dealt with questions pertaining to community support and funding options, Taltran s Community Attitude Survey focused on advertising issues and comparing transportation options within its community. Figure 4 through Figure 12 depict the responses given by the other communities. The Orlando (LYNX) surveyors asked respondents to pick one response whereas the rest of the communities were asked to respond to each of the improvements individually. PalmTran and JTA residents who do not currently use the bus were asked if they agreed that they would ride the bus once per month or more if specific improvements were made to the system. In contrast, MDT surveyors asked non-riders and potential riders whether certain service improvements would make them consider using transit. Non-riders were considered, persons 16 years of age and older who did not use public transportation and have no intention of doing so under any circumstances. Potential riders were defined as, persons 16 years of age and older who used public transit at least once in the past year or saw themselves riding Metrobus or Metrorail at least a few times over the next twelve months, or would consider using Metrobus or Metrorail in Miami-Dade County if 
certain services were expanded or improved. In most cases, the options given to the respondents were different; however, there are some similarities. The most frequent options given to respondents include bus routing, service span, frequency, safety/cleanliness, and on-time performance.

Several Florida transit communities most frequently cited that routing buses close to places they want to go will persuade them to ride transit. As Figure 4 depicts, when asked, Would any of the following things make you more likely to use the Hillsborough County bus system?, the community s respondents most frequent response was that bus stops need to be close to wanted destinations (64 percent).

Similarly, Jacksonville residents most frequently suggested close bus stops to home and work (53 percent), as shown in Figure 5. In Figure 7, Metro-Dade s potential riders most frequent response was that they would, consider using Metrobus or Metrorail in Dade County, if transit took them closer to work. Additionally, Orlando residents also agree since their most chosen response (18 percent) that would make them consider using the LYNX service is to place more buses in my area, as depicted in Figure 6. Moreover, Figure 9 shows that Palm Beach respondents most frequently chose stops closer to home and work as an improvement that would persuade them to use PalmTran at least once per month Finally, 45.5 percent of Broward County respondents agree that direct routes where I want to go would make transit more attractive.

Other frequently discussed enhancements included improving service. Lesser headways, reduced transfers, and better on-time performance were chosen more often than other enticements. Surveyed residents in the communities where BCT, HART, JTA, MDT, Palm Tran, and PSTA reside prefer shorter headways. The length of the headways ranged from 10 minutes to half an hour. In fact, Hillsborough and Jacksonville residents (Figure 4 and Figure 5, respectively) chos e making headways shorter as their second most frequently cited response (60 percent of Hillsborough respondents indicated that they want service every 15 minutes while 52 percent of Jacksonville respondents indicated that they would like 30-minute headways ). Moreover, Hillsborough and Pinellas respondents want more direct route service. In Figure 4, 56 percent of Hillsborough respondents reveal that they would be more likely to ride the bus if they had service every 15 minutes. Pinellas respondents feel that PSTA providing 15 minute headways instead of 30 is a 9 on the importance scale (where 10 rates as very important). In a general statement, 30.2 percent of Broward County respondents chose more frequent and convenient buses as an improvement that would make transit more attractive. Additionally, better on-time performance was cited by 43 percent of Jacksonville s respondents (Figure 5) and 77 percent of Miami-Dade s (Figure 7) potential riders. When non-riders and potential riders of MDT were asked the service improvements that would definitely get them to use transit, a majority (52 percent) stated, buses arriving and departing ontime, as shown in Figure 8.

Although safety is a concern, increasing safety was not chosen as frequently as other items. This is 
probably due to the fact that small and midsize transit agencies can offer more personalized attention, such as familiarity with bus drivers and routine passengers. However, safety concerns were frequently cited by those in the two largest metropolitan areas in Florida, Metro-Dade and Jacksonville. In fact, over 70 percent of MDT s potential transit riders listed feeling safer when using Metrobus and Metrorail as a consideration. Similarly, 45 percent of the respondents from Jacksonville s community survey would consider to use the bus at least once per month if, buses were cleaner, safer, and more comfortable.

A section of MDT s survey specifically addressed the safety issues its passengers and potential passengers encounter. It was determined that those who are the most exposed to public transportation perceive transit to be safer. Hence, riders are less worried about safety than potential riders and potential riders are less worried about safety than non-riders. Transit stops during the daytime are perceived to be safer than during the nighttime. In rank order, being at a bus stop during the day, is safer than, actually riding the Metrobus or Metrorail, and riding transit is safer than, being at a bus stop or train station at night. Comparatively, public transportation in Miami-Dade is perceived to be safer than driving a busy interstate (I-95), getting money from an ATM, or going to the grocery store at night. Unfortunately, all of the surveys were completed before the terrorist attack on September $11^{\text {th }}, 2001$. Public safety concerns may be understated compared to the present environment of terrorist presence in the United States of America.

Although some claim that they would take transit if these service enhancements were made, some may consider it but not actually ride even when positive service measures are completed. Hence, the ability of the features to attract non-users to become users may be less than indicated. Some may seriously consider taking transit, but may not follow through due to a variety of reasons. For instance, 34 percent of LYNX non-users claim that they have seriously considered taking the bus, but have not followed through. Lack of familiarity of using the bus may prevent some from trying transit even if they are willing to consider it.

In contrast, some residents said that nothing would make them choose taking the bus over using their automobile. In Figure 6, four out of ten (39 percent) Orlando non-users claim there is nothing LYNX can do to increase their likelihood of considering riding the bus, stating that they are either not interested because they drive a car or that nothing would change their mind. Additionally, MDT s study reported that the primary reason potential riders and non-riders do not ride MDT in 1997 remains the same as was reported in the past several waves. The use of public transportation is perceived as inconvenient among both potential riders and non-riders. Finally, 75.5 percent of Broward County respondents indicated that the main reason they have not used BCT buses is that they prefer driving a car.

Automobile access is also the top reason why former riders no longer ride transit, according to JTA and 
PalmTran surveys. As depicted in Figure 11, 45 percent of JTA s former riders stated the reason that they no longer take the bus is because they bought or got access to a car whereas on-time performance was the second most frequent reason ( 22 percent). Of PalmTran s former riders, 58 percent said that the main reason they no longer ride the bus is due to the fact that they got a car while the second most frequent answer was that bus was not available at their new work site (13 percent). Consequently, it seems that the convenience of an automobile makes the transit option less desirable for those who are familiar with taking transit as well as those who have never used transit before.

\section{Funding Sources}

The level of support is related to community image. For instance, the more support residents have for public transportation, the more likely transit-based initiatives will receive political support in terms of voting and funding. Since the image of public transportation in Florida is relatively good, political support for transit initiatives should fare well, too. Some of the communities in Florida directly asked their residents about particular funding issues. As a caveat, please note that the respondents of these survey questions were randomly sampled from their community rather than just registered voters. Consequently, individuals who actually vote in referendums concerning taxation may respond differently. Fiscal questions varied from overall county-wide transportation planning goals to transit-specific stewardship of public money.

Hillsborough County asked residents their opinions to determine public support in general long range transportation goals. Residents answered the question, which long range transportation goals were the most important? According to the results, the majority (56.8 percent) chose improving traffic flow as much as possible. Developing viable alternatives to driving was also picked frequently ( 23 percent). For comparison, the other options were spending as little county tax money on transportation as possible (6.5 percent) and reducing road noise and pollution as much as possible (13.8 percent).

A couple of Florida communities asked whether certain transit enhancements deserved additional taxpayer support. In both Jacksonville and Orlando, the improvements that are strongly supported include expanding span of service and routes. In fact, providing bus service to more parts of town was chosen by 79 percent of the Jacksonville respondents. In addition, the Jacks onville respondents strongly agreed with providing more early morning bus service (76 percent) and making buses operate on schedule (73 percent). According to Orlando residents, 61 percent agreed with more weekend service (3.75 mean), 59 percent agreed with more holiday and later nights (3.75 mean), and 58 percent agreed in expanding weekday hours of service (3.66 mean). Moreover, geographic coverage was supported by 59 percent of the Orlando respondents (3.70 mean). Although improving service span and routing were the most frequently cited responses by both cities, 60 percent of the Orlando respondents favored taxpayer

Page 34 of 61 pages 
support for building and operating a rail system (3.65 mean). In contrast, less than half (47 percent) of the Orlando respondents supported increasing taxes to reduce LYNX s fares (3.19 mean). While both Jacksonville and Orlando community surveys indicated that there is additional funding support for transit, a minority said that they would not vote for transit-based initiatives.

Personal usage of transit is not always a prerequisite for the support of a transit initiative. For example, according to the Orlando community study, two-thirds (58\% strongly disagree and $8 \%$ somewhat disagree) of the respondents disagree that personal usage is a prerequisite for the support of a public transit initiative. In addition, although 96 percent of the respondents in Winter Haven reported that they have never ridden WHAT, 94 percent of the respondents were in favor of WHAT. Although both communities show support for their transit systems, providing future improvements by increasing taxes could still be a challenge.

Several communities were asked whether they would vote against funding a public transportation improvement. Of the Jacksonville respondents, 10.2 percent indicated that they will always vote no for anything involving a transit improvement . However, 80 percent of the Jacksonville respondents indicated that they would consider funding improvements. Similarly, when Orlando respondents were asked to agree or disagree with the statement, I don $t$ use public transit, so I will always vote no for anything involving a transit improvement, almost 20 percent ( 7 percent completely agreed and 12 percent somewhat agreed) agreed with it while 13 percent were neutral, 8 percent somewhat disagreed, and 58 percent completely disagreed. In Palm Beach and Broward, support for increased tax funding to improve transit is mixed. Some (11 percent) of the Palm Beach respondents were neutral or did not know; only 45 percent (15 percent strongly agree and 30 percent somewhat agree) did support additional funding for transit while 44 percent (16 percent somewhat disagree and 28 percent strongly disagree) did not support additional funding. While half (51.2 percent) of the Broward County respondents agree that they would support additional funding dedicated to public transit, 40 percent responded negatively while 0.5 percent said maybe and 8.3 percent did not answer. Also, Hence, funding support for transit seems to be strong in some communities and weak in others.

Hillsborough County respondents were directly asked if their taxes should be increased. The most common response (63.5 percent) was to increase some taxes to fund the highest priority projects. More than a quarter of the respondents (25.6 percent) wanted to leave taxes at the same levels and accept transportation conditions as they are. A general increase taxes to fund more projects statement received the least support (10.9 percent). Although these answers were not transit-specific, as long as transit is included as one of the high priority projects within the community, it seems that support is positive for it in Hillsborough. 
Some communities (Hillsborough, Winter Haven, Orlando) were interested in the type of funding that their citizens preferred. For all three communities, the most preferred type of tax is sales tax: 20 percent of Winter Haven respondents, 50.7 percent of Hillsborough respondents, and 31 percent of the respondents in Orlando. In Winter Haven, many interviewees were comfortable with sales tax because it encompasses everybody in the community, unlike an ad valorem tax that is paid only by property owners and a gas tax that is paid by only those who drive their own vehicle. Gas tax was the next frequent response ( 25 percent of Orlando respondents and 28.1 percent of Hillsborough respondents), followed by property tax (16 percent of Orlando respondents and 16.2 percent of Hillsborough respondents). Finally, in Winter Haven, almost a third of the respondents preferred the ridership to pay for all or most of the service via fares $(29 \%)$.

Specific dollar amounts of tax increases per person were studied by LYNX in Orlando. Orlando respondents were given several per person tax amounts and asked them to state their willingness to pay. The tax amounts ranged from $\$ 25.00$ to $\$ 100.00$ per person annually. Total willingness to pay taxes decreases as the amount of taxes increases. For example, fifty-nine percent are unwilling to pay an addition $\$ 100$. However, more than half (52 percent) are willing to pay an extra $\$ 50$ and 72 percent are willing to pay an additional \$25 annually to expand LYNX s services.

Finally, a large metropolitan county was interested in whether transit is perceived to provide good stewardship of its revenue. Dade County potential rider and non-rider respondents were asked to rate whether, the Miami Dade Transit system does a good job of using the tax money that it receives. The users and potential users of transit rated stewardship higher than the non-riders. For instance, less than half of the non-riders (46 percent) agree that the transit agency is doing a good job. In contrast, 57 percent of MDT potential riders and 73 percent of those who use MDT services were confident of transit s tax revenue stewardship in Miami-Dade County.

\section{Summary}

The image of public transportation within Florida is positive. According to most, transit provides an adequate to good transportation alternative to get around. Also, transit is seen as a vital service to the community. Many Floridians see it as an important part of solving transportation problems, supporting the local economy, and improving quality of life. In addition, the perceived need for transit has increased. Residents believe that transit is not just for those without an automobile. Most consider it a transportation mode for everyone. Some have thought about taking the bus, even though they did not follow through and ride it. Unfamiliarity of using transit may cause people not to try it. Although those who support transit may not be interested in riding it themselves. 
One of the most common hurdles transit has to overcome in Florida is making public transportation more convenient. Florida residents most common reason for not riding transit is the need for buses to drop them off at locations they want to go, especially home and work. Another frequently cited request is to make headways more often. Although residents requested a range of headways, from 10 minutes to half an hour, this may be a large expense for transit agencies, especially if lowering headways require more vehicles and additional drivers. However, lowering headways during rush hour could appeal to work commuters and would not be as expensive as decreasing headways for all routes. Other service-related enhancements include more direct routes and consistent on-time performance. Safety concerns are more prevalent in transit systems with bigger fleets, usually residing in metropolitan regions. However, the terrorist attacks of September $11^{\text {th }}$ may have altered the public s perception of safety. Accordingly, this is an area that would warrant additional study in the future. Finally, automobile accessibility brings more flexibility and convenience. Some non-users will said they will not consider using transit because they have a car. Other non-users may consider transit only in desperate situations, such as when their car breaks down and they need to get to work. However, some non-users may use transit for trips if it is convenient in location, includes an acceptable time frame, is reliable, and is perceived to be safe.

Funding transit service improvements is challenging in Florida. However, tax initiatives to improve transportation conditions, such as congestion, seem to have support. If transit is within a transportation taxation package, it may be more acceptable. The transit projects that received the most funding support were providing more transportation alternatives, increasing service span (weekends, holiday, earlier, later) and geographic coverage (bus stop close to home and work). One community, Orlando, highly supported funding a rail system.

In general, Florida communities did not support further fare subsidies. Additionally, the willingness to support a tax depended upon the amount. As the amount of tax increases, the willingness to pay (vote) for the tax decreases. Floridians prefer sales taxes to gas taxes and property taxes. The most commonly cited reason was because everybody pays sales tax. Finally, users rate tax stewardship by transit higher than non-users. Perhaps this is due to the fact that users rely upon transit for at least some of their transportation needs. Transit may also be a users only option. Consequently, if a user needs transit to get to work, it would be valued highly. In addition, those who experience transit may rate stewardship higher because they are familiar with the service.

The Florida communities who were surveyed show interesting similarities. A typical Floridian non-user tends to support transit, but is not inclined to ride it. They prefer to drive automobiles. Non-users and former users state that the main reason they do not use transit is due to the fact that they have accessibility to a vehicle. Some have thought about using transit on occasion, but have never followed through. It would be interesting to be able to find out why they did not take it-perhaps, due to lack of knowledge on 
how to take a bus or the bus did not go where they needed to go or there was not a direct, quick route. In contrast, maybe it wasn $t$ because of service but due to them getting a neighbor to take them instead. It could be something else. Who knows? Nobody asked. Usually, transit providers choose to make operational changes based on current ridership needs and wants. This is a practical thing to do in order to keep their customers happy. However, transit in its current form tends to serve only those who are desperate and have no other options. In order to attract the non-user, transit must above all else be convenient. How do we make transit more convenient for the non-user? That is a question that cannot be answered by the surveys. A subsequent study that randomly samples Florida residents with a comprehensive survey that has a sole purpose of marketing non-users would be necessary. 
Figure 1

How good a job has public transit done at providing ways to get around the community?
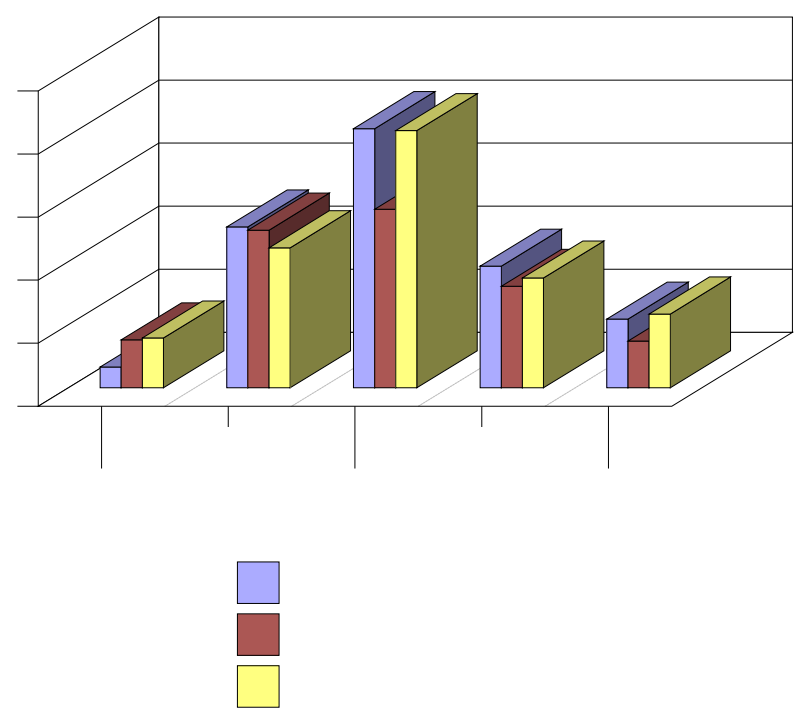

\section{Figure 2}

Public Transportation is Just for Those Who Cannot Afford A Car

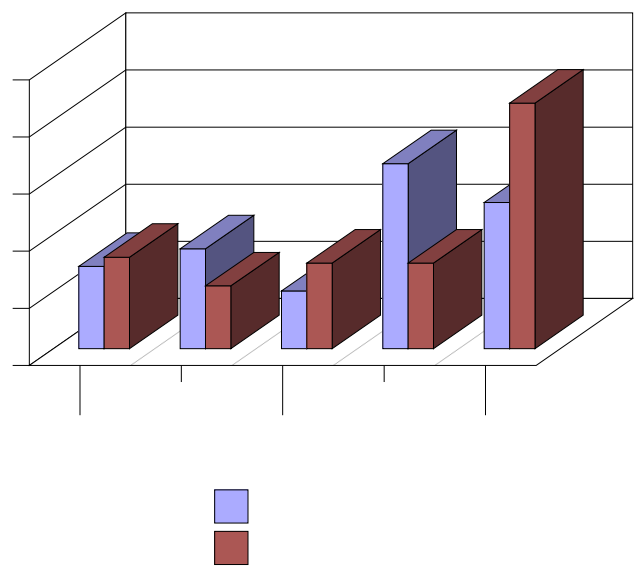

Page 39 of 61 pages 


\section{Figure 3}

An effective Public Transportation System is Important for the Local Economy.

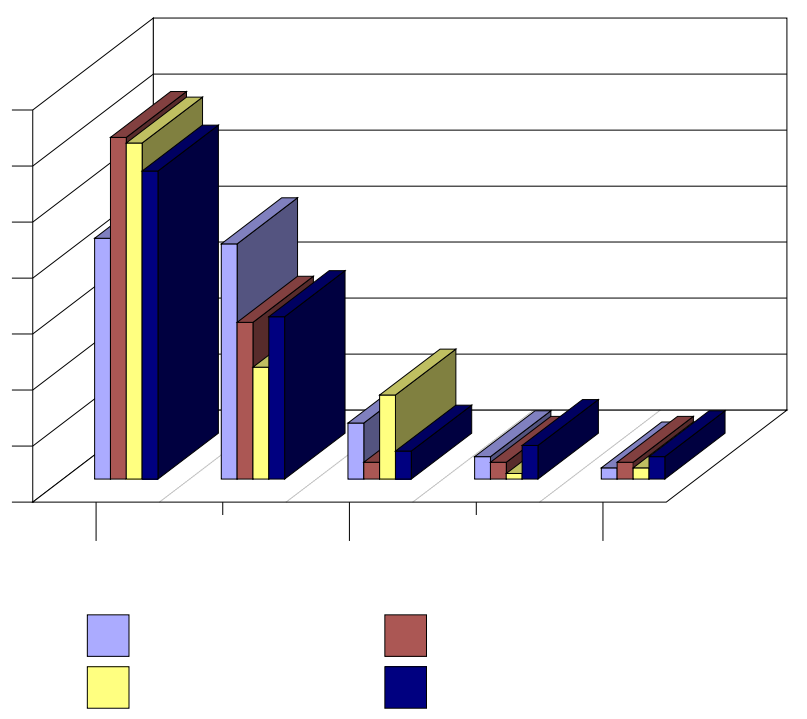

Page 40 of 61 pages 


\section{Figure 4}

HART: Would any of the following things make you more likely to use the Hillsborough County bus system?

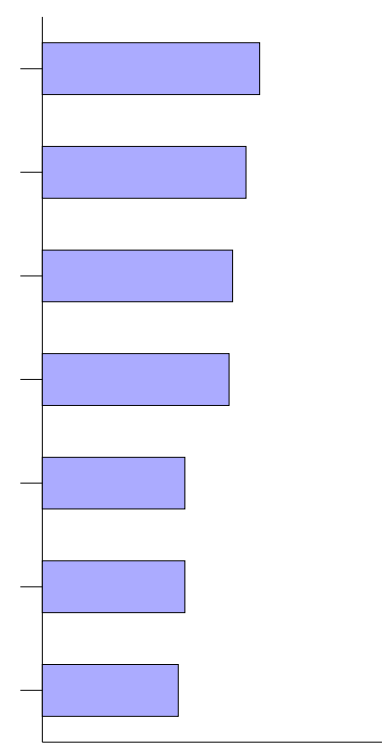

\section{Figure 5}

JTA: Would You Ride the Bus Once Per Month or More If Improvement Was Made to the System?

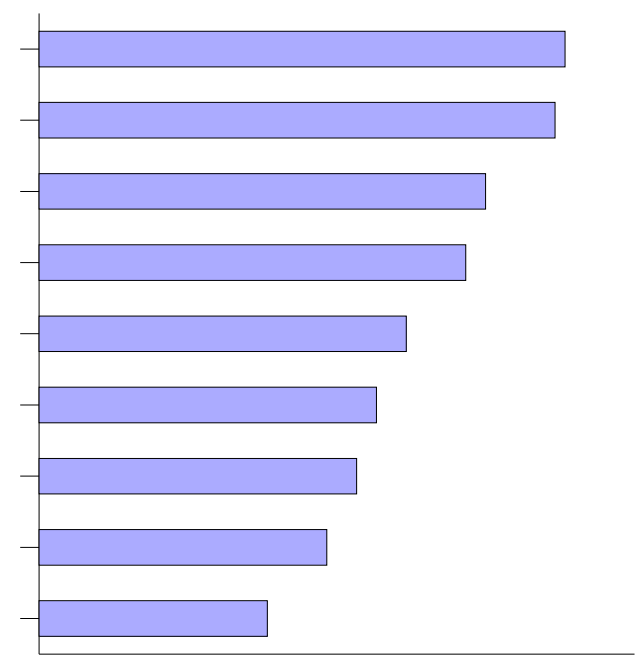




\section{Figure 6}

LYNX: What can LYNX do to Increase the Likelihood that you will use a LYNX Bus or Other LYNX Service? (Openended question)

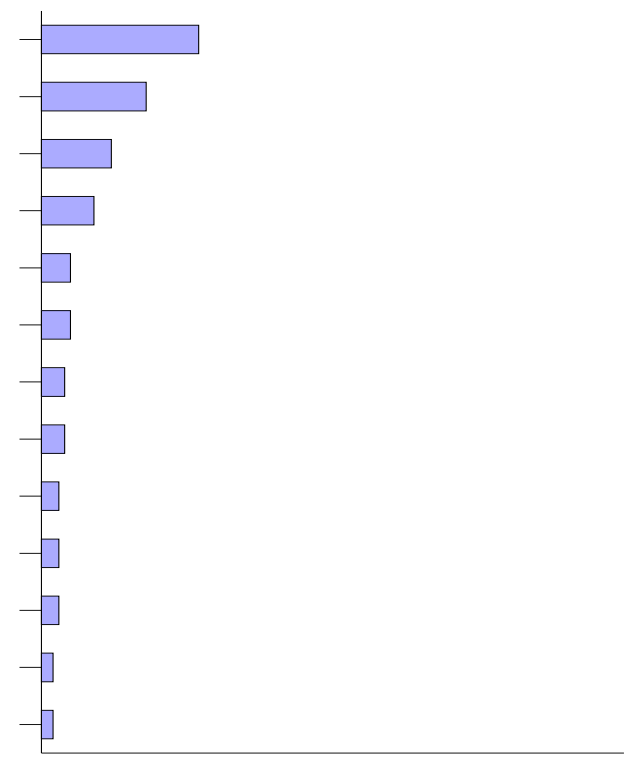

Figure 7

MDT: Would you consider using Metrobus or Metrorail in Dade County if...

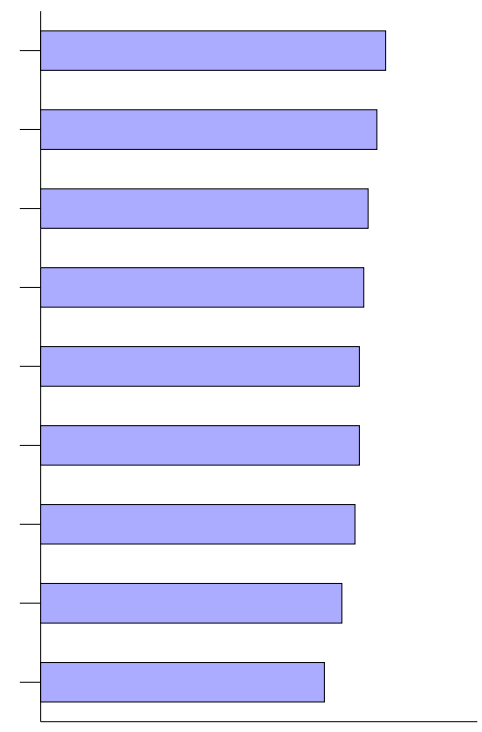

Page 42 of 61 pages 


\section{Figure 8}

MDT: Which of the potential improvements might change use of transit?

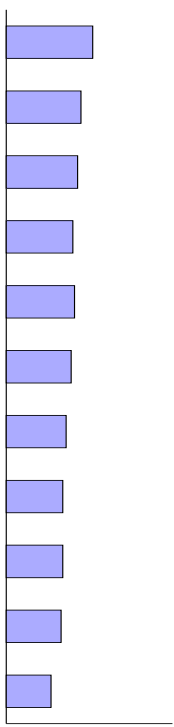

Figure 9

PalmTran: Would You Ride the Bus Once Per Month Or More If Improvement Was Made to the System?

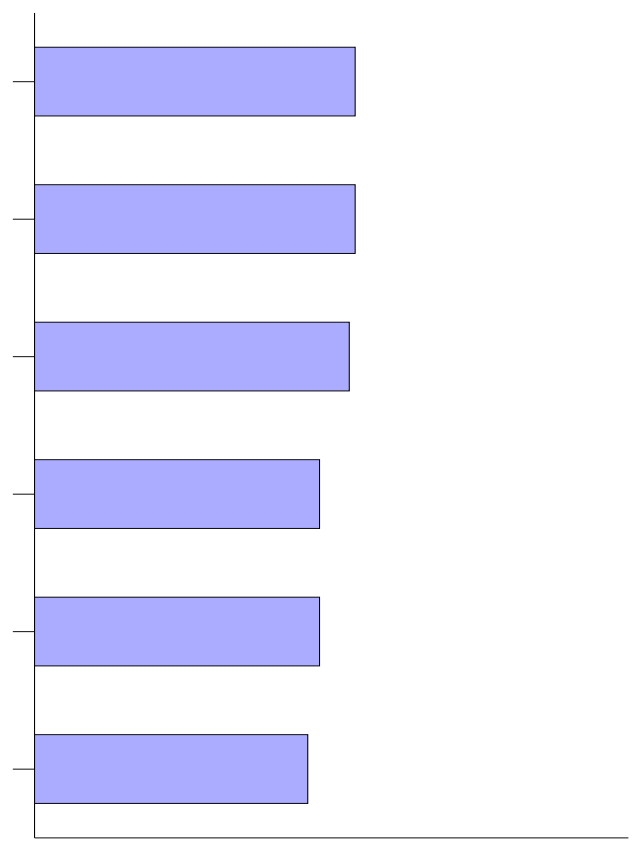

Page 43 of 61 pages 


\section{Figure 10}

PSTA: If they wanted to make it worthwhile for you to use the bus regularly, how important would it be for PSTA to do each of the following? ( $1=$ not important to $10=$ very important $)$

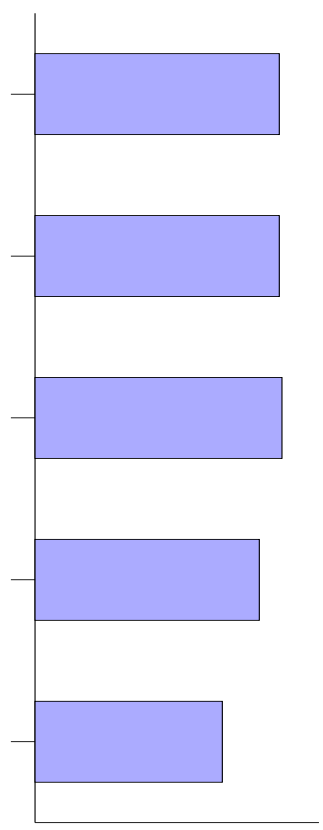


Former Riders Reasons for Not Taking the Bus

Figure 11

JTA: Percentage of Former Riders Strongly Agreeing with Statements About Why They No Longer Use the Bus.

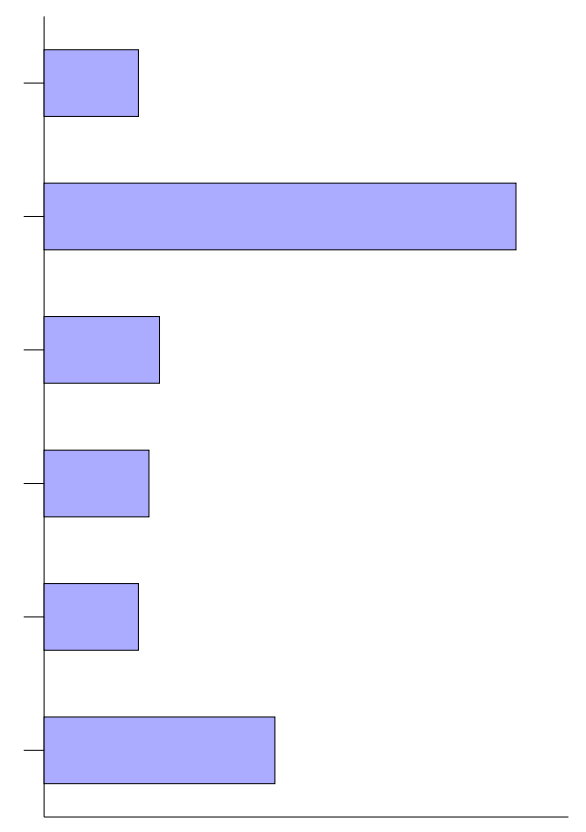

\section{Figure 12}

PalmTran: What is the Main Reason You No Longer Ride the Bus? (Choose one answer)

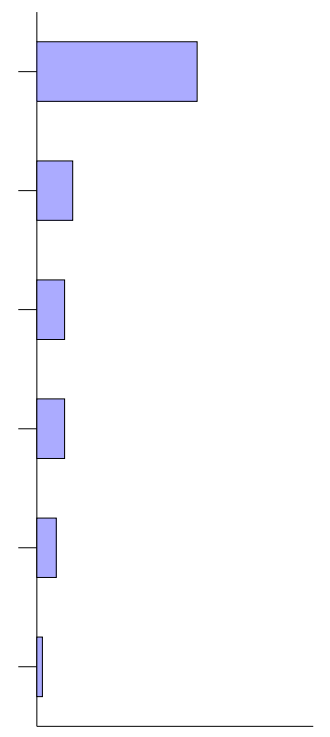

Page 45 of 61 pages 


\section{CHAPTER 4}

\section{ADDITIONAL INFORMATION}

\section{Florida Focus Groups}

\section{Brevard County, FL}

In 1994, Space Coast Area Transit (SCAT) in Brevard County, FL hired the Center for Urban Transportation Research (CUTR) to conduct three focus with non-users for their Transit Development Plan. The non-users cited the convenience of the automobile as the largest reason for not using transit. Hours of operation, reliability issues, and the need to take multiple trips were given as obstacles to transit use. Several participants noted that a major reason for them not utilizing the bus was because they lacked knowledge about routes and schedules. Also, some agreed that they need the flexibility of transfers between routes, which was not available at that time. Finally, even though they believe that there is a need to reduce the number of vehicles on the road, many of the participants agreed that the bus system is for individuals with no other alternatives. Since the transit system was not familiar to them, participants suggested marketing tools, such as promoting an education program to reshape public views of the system. Other suggestions were advertising bus schedules and routes in community papers, utilizing a public access cable channel, and posting an easy to remember information number on buses, billboards, and in local papers.

\section{Manatee County, FL}

Manatee County Area Transit (MCAT) also utilized the Center for Urban Transportation Research to conduct a non-user focus group for their Transportation Development Plan (1995). Again, the major reason for not using transit is the inconvenience. Bus frequency was above their reasonable wait time of 15 minutes. Also, the nearest bus stop was too far from their residence and destinations of interest. Secondly, participants reported they lacked information about the system s routes, schedules, operation hours, and fares. Moreover, the route maps and schedules were confusing. There were some positive responses, such as the bus was perceived to be clean, safe, and a somewhat relaxing way to travel. However, these positive comments did not outweigh the relative appeal of the convenience of the automobile.

\section{Tampa, FL}

During 2001, two focus groups in Tampa, FL were formed by CUTR to determine reasons for not using public transportation, especially considering the public s perceptions of transit safety. The groups determined that infrequency and lack of convenience were the primary reasons why buses are not used for transportation. Second, individuals were uncomfortable with riding with other passengers, primarily because they do not want to associate with the lower-class. In fact one statement suggested, having to 
use public transportation (in this region) is perceived as an indicator of the failure to obtain the American Dream . Other fears include being victims of crime while walking to/from bus stops, waiting at the bus stop, and while riding public transportation. These focus groups were led before the September $11^{\text {th }}$ terrorist event. The public may judge safety differently in the post-September $11^{\text {th }}$ world due to fears of potential terrorist attacks.

\section{Non-Florida Studies}

\section{Minneapolis/St. Paul, MN}

Metro Transit conducts a study of the commuters who do not use their transportation services. It is conducted every two years in order to determine the current awareness of the transportation available and the attitudes of consumers who are not using their services...to better attract people who are not currently using services provided by Metro Transit. Resident respondents were found to be more likely to use transit in 1999 than in 1997. In fact, although the 1999 respondents did not use public transportation in the Minneapolis/St. Paul region, 40 percent were at least somewhat likely to take transit within the next two years. Those who considered using the bus within year 1999 (two percent) perceived that it was less costly and more relaxing than driving their own car. Participants with an available shuttle and bus stops closer to home were more likely to be attracted to transit. Those who responded neutral in the appeal of the bus indicated the lack of convenience as their stance. Employees who found the bus unappealing suggested lack of convenience and safety concerns as barriers.

Overall, residents of Minneapolis/St. Paul cited lack of control, knowledge, and safety that prevents them from riding Metro Transit. Additionally, having a car appeals to them due to the fact that their children need to be transported before and after work, errands are taken before and after work, and in case of an emergency. Moreover, many are unaware about how to take the bus, including how to obtain and use scheduling information. Finally, length of time the bus takes compared to an automobile was cited by nearly 84 percent.

There were a few suggestions on how to attract these residents to be patrons of transit. Special services, such as a guaranteed ride home and personalized scheduling advice were attractive. Also, discounted fares ranked high. Even though almost 96 percent of the respondents spoke English as their first language, over 80 percent of them agreed that bus information should be available in other languages spoken in their region (Spanish, Hmong, and Somali). More than half of the commuters supported an increase in taxes to improve the bus service. 


\section{Oshkosh, Wisconsin}

When patronage dropped, a questionnaire was developed in 1981 by the members of the University of Wisconsin for Oshkosh Transit System (OTS). The intent of the survey was to increase ridership by attracting work commuters in Oshkosh, Wisconsin by observing employees journey-to-work patterns of individuals and their attitudes toward bus transportation. In order to increase the number of people who take the bus to work, differences and similarities between users and non-users of transit were analyzed. Eighty-five percent of the respondents indicated that they were non-transit commuters. Hence, only 15 percent utilize the bus to get to and from work at least once per week. Also, 64 percent of the respondents lived within two blocks of a bus stop. During the summer months, people using the bus for work decreased due to more people walking, bicycling, or riding with someone else. The respondents were asked to rate nine improvements on a scale of 0 to 10 . The improvements that were rated over five include bus arriving 5 to 10 minutes before work starting time, better information about the bus system, sheltered waiting stations, 15 minute headways during rush hours, and a monthly fare pass allowing unlimited number of rides. 


\section{CHAPTER 5}

\section{POLICY RECOMMENDATIONS}

In view of the information presented in the previous chapters, we recommend several policy changes in order to improve public transit ridership in Florida. Number one among these suggestions is an employee subsidy program which will give commuters an incentive to ride transit to work. One of these employee subsidy programs is called CommuterChoice (www.commuterchoice.com). CommuterChoice is a nationwide partnership designed to help employers create customized solutions to their employees commuting challenges. CommuterChoice also includes communities working with residents, schools working with students, and even developers working with future tenants to help provide and promote commuting choices. It is hopeful that programs such as CommuterChoice can help to target non-users and make public transit more attractive to them.

Non-users of transit tend to perceive transit safety more negatively than users (Reed et al., 1999) and this perception must be addressed if we are to encourage transit use among non-users. There are some realities to this perception and the placement of bus stops is very important to ensuring passenger safety. Bus stops placed near alleys, mid-block passages, multi-family housing, liquor stores, buildings marked graffiti and litter tend to be more crime prone (Loukaitou-Sideris and Liggett, 2000). Additionally, non-users of transit with safety concerns suggested that they would be more likely to use transit if additional lighting and telephones were added at bus stops (Cleland, 2002).

Not only is the infrastructure of the transit system and placement of stops very important to both perceived and real safety from crime, it is also important to protecting transit users from unsafe roadway conditions. Negatively perceived roadway factors were determined to be street crossings with wide facilities, freeflowing or multiple lanes, and streets with no curbs, and/or sidewalks. If transit systems expect to appeal to non-users of transit, then they must ensure safety from crime and also safety from roadway conditions. Adequate crossing areas, signage, and traffic signals must be provided for safe access and egress to and from transit stops. Many newly developed areas are not pedestrian friendly and are therefore not transit friendly.

One of the most important factors for commuter non-utilization of public transit is the comparative attractiveness of personal automobiles. Non-users prefer the flexibility and time-savings of using their personal automobiles and any efforts to reduce personal automobile commuting will be met with resistance unless we can reduce this breach in flexibility and convenience between public transit and personal vehicles. We suggest considering adding enhancements to Florida public transit systems such as:

* [ express fixed-route service,

* dedicated bus lanes, 
* [ bus stops near home and work,

* [ minimal transfers,

* [ no-wait transfers when necessary, and

* mini-van shuttle service from and to pick-up and discharge points within one block of origin and destination in order to attract more non-users to public transit.

An additional barrier to using public transportation exists for those responsible for transporting children. Having a car appeals to these commuters because their children need to be transported before and after work, errands are taken before and after work, and in case of an emergency. This is especially problematic for persons who must transport pre-mobile children and also children too small to adequately use transit without constant supervision. Suggestions for attracting these customers are services such as: * [ guaranteed ride home,

${ }_{\star}$ [ personal scheduling services, and

${ }_{*} \mathrm{C}$ discounted family fares.

When using a personal vehicle to commute, the driver is able to choose a certain route from origin to destination. This is not so when using public transit, which consist of a fixed route. M any researchers (Everett et al., 1997; Abdel-Aty \& Jovanis, 1995) have suggested that current maps and pamphlets provided by transit systems are not sufficient in providing information to the general public about how to easily get from their origin to their destination. Many transit systems have seemingly resolved this problem with maps, specifying different colors for different maps. However, a study by Hardin (2001) found that bus schedules and maps, even when produced in multiple colors for ease of understanding are not effective. This is because the general public does not intuitively understand how to read a map of a transit system. Several studies have suggested both website and kiosk interactive services which would allow transit users to input an origin and destination and receive a personalized transit plan (Abdel-Aty et al, 1996; Southworth, 1996; Horton and Gillig, 1997). In addition, AVLC technology at major bus stops and transfer centers could provide up-to-date information about exact arrival and departure times to assure transit users and provide them with a sense of control over the transit experience (Whelan, 1988). Based upon these findings, we suggest that Florida transit systems may attract non-users of transit to use their systems by offering user-friendly, interactive personal travel plans via the web and also via kiosks available at major transfer points. Customer comfort and convenience can be further enhanced by providing up-to-date arrival and departure times via AVLC technology at major service hubs and transfer stations.

Horton and Gillig (1997) studied the advantages of a website in relation to transit agencies and commuter assistance programs. According to their research, those who typically use websites have demographics similar to the non-user (i.e., white males in mid- to high- income brackets). Websites could allow transit 
agencies the opportunity to market to this elusive demographic group. By answering frequently asked questions (FAQs) and explaining the services offered, websites can alleviate the anxiety of potential transit commuters.

A marketing plan that considers demographic characteristics can be useful. By targeting people demographically, the impact of marketing can be maximized. Marketing campaigns that minimize negative public perceptions and instill a sense of community responsibility are needed to promote a better image of public transit. Emphasizing the positives of using public transit is very important to minimizing perceptions of public transit stigma, that only those who cannot afford a car would use public transit. Better environmental health, less sprawl, and less traffic congestion are all good reasons to use public transit. However, many non-users will continue to use private vehicles in spite of these valid positive incentives to use public transit. Negative incentives to use public transit such as raising gasoline prices, road tolls, parking costs, and increased traffic congestion may increase transit ridership. However, we suggest using positive incentives in any marketing campaign prior to unleashing disincentives upon the general public in an effort to convert non-users to users of public transit.

Finally, transit systems must provide convenient service to places of interest. These measures could entice choice riders as well as visitors to public transit in Florida.. Hardin (2001) studied access to important Florida activity centers, such as airports, medical centers, shopping centers, business/government centers, recreational facilities and educational centers to determine how well transit served those areas. Most of the activity centers were found to be accessible by transit, but not at the most convenient or necessary times, such as late at night or early in the morning. Hardin (2001) also found that airports had the lowest level of service and business/government centers had the highest level of service. Further, the study found that service to shopping centers and recreational centers on the weekends, usually a peak usage period, was lacking. Hardin (2001) suggested enhancing bus service based upon activity center hours of operation and usage patterns. These suggested improvements could attract quality riders, including students and airport, hospital, and shopping center employees. Additionally, enhancing weekend and evening service to activity centers could also encourage local residents to use transit for recreational trips. 
In summary, it is important to address the concerns of convenience, safety, and social stigma as primary barriers to attracting non-users. The following list summarizes our suggestions for policy changes and implementations which will be most effective in attracting non-user ridership to Florida public transit systems:

* Offering employer incentives to use public transit.

* $\quad$ Combining Park-and-Rides with Express services for commuters to ride from dense residential communities to high employment areas.

* 4 Addressing safety concerns:

${ }_{*}[\quad$ Loukaitou-Sideris and Liggett (2000) suggest careful planning and consideration in choosing placement of transit stops as well as additional lighting and emergency telephones placed adjacent to bus stops as a barrier to crime while using transit

${ }_{*}$ Adequate crossing areas, signage, and traffic signals must be provided in order to ensure pedestrian safety in accessing bus stops.

* $\mathrm{C}$ Addressing convenience concerns:

${ }_{*}[\quad$ Adding enhancements to Florida public transit systems such as

- $\quad$ express fixed-route service,

- dedicated bus lanes,

- bus stops near home and work,

- minimal transfers,

- no-wait transfers when necessary, and

- mini-van shuttle service from and to pick-up and discharge points within one block of origin and destination in order to attract more non-users to public transit.

* $\quad$ Florida public transit should offer user-friendly, interactive personal travel plans via the web and also via kiosks available at major transfer points.

${ }_{\star} \square$ One study suggests that persons transporting children may be encouraged to use transit if they were offered such services as:

- guaranteed ride home,

- personal scheduling services, and

- $\quad$ discounted family fares.

${ }_{*}[\quad$ Overcoming social stigma and generating more transit ridership among non-users:

${ }_{\star}[\quad$ Marketing campaigns that minimize negative public perceptions and instill a sense of community responsibility are needed to promote a better image of public transit.

- Emphasizing the positives of using public transit is very important to minimizing perceptions of public transit stigma, that only those who cannot afford a car would use public transit.

- Better environmental health, less sprawl, and less traffic congestion are all good reasons to use public transit.

${ }_{\star}[\quad$ Negative incentives to use public transit such as raising gasoline prices, road tolls, parking costs, and increased traffic congestion may increase transit ridership.

* Transit systems must provide convenient service to places of interest. Enhancing bus service based upon activity center hours of operation and usage patterns.

${ }_{*}$ Q Websites could allow transit agencies the opportunity to market to non-users as well as using the website to answer FAQs and alleviate any concerns the possible transit user might have.

\section{CHAPTER 6}

\section{SURVEY METHODOLOGY GUIDANCE}


Most of the community public transportation surveys performed by or for Florida Transit systems are phone surveys. As mentioned in Chapter 3, each one of these surveys were designed differently based upon the purpose of the study. System size played an important role in the length and depth of each survey instrument. Smaller, newer systems usually asked questions related to only one theme, whereas larger, more established systems tended to ask questions in order to gather data on a variety of topics, especially improving services and operations.

When developing a survey, the project manager needs to develop a list of priorities to help him or her develop the appropriate questions, such as:

* What decision needs to be made with this data?

* W What type of information needs to be gathered to help make this decision?

Additionally, the survey manager and project manager must reach a consensus on what type of survey is appropriate. For example, if we are trying to interview non-users of transit, we obviously would not be interviewing people at a public transit terminal. Instead, we would try to do a random dialing survey to call various members of the community, or perhaps perform personal, face-to-face surveys in a public meeting area, such as a shopping mall. In the surveys seen in Chapter 3, there were three methodologies employed: telephone survey, mail survey, and personal survey, although the majority of surveys in Chapter 3 employed telephone data collection as their methodology. Cost is also a very important factor in deciding which type of data collection efforts will be most efficient for the type of data required. Focus groups can provide qualitative data on important issues which are worthy of further study, and they are also the least expensive type of data collection to perform. Telephone surveys are the most expensive type of surveys to perform and written surveys are in the middle of the cost scale.

\section{Table I}

\section{Strengths and weaknesses of data collection methods.}

\begin{tabular}{|l|l|r|r|}
\hline Focus Groups & Inexpensive & Qualitative Data & No quantitative data \\
\hline Written survey & Moderately expensive & Quantitative Data & $\begin{array}{r}\text { Problems with response } \\
\text { rates }\end{array}$ \\
\cline { 2 - 3 } Telephone survey & Most expensive & Quantitative data & Best response rates \\
\hline
\end{tabular}

Some of the more useful question categories for data gathering are listed in Chapter 3 and we summarize those questions here:

* Community Image Assessment of Public Transit System 
* How good a job has public transit done at providing ways to get around the community?

* Has the service of this public transit provider improved in the past year?

* To what extent do you feel the need for public transit service in the community has changed?

* Public transportation is an important part of solving our local transportation problems.

* [ Public transit really improves the quality of life in the area.

* Public transit is an important service for the area.

* P Public transit is only for those without access to an automobile.

* An effective public transportation system is important for the local economy.

${ }_{\star}$ [ Overall, how would you rate the public transit system in this area?

* [ Service Improvements to Increase Ridership

* W Would any of the following service improvements make you more likely to use this community $\mathrm{s}$ public transit system?

- Stops closer to work and home

- Lesser headways

- $\quad$ Reduced transfers

- Better on-time performance

- More frequent service

- Direct routes

- Improved safety

- Expansion of routes and hours

* $\mathrm{C}$ Funding Sources

* Which long range transportation goals are the most important?

* W Which transit service enhancements deserve additional taxpayer support?

* Personal usage of a transit system is a prerequisite for the support of a public transit initiative.

* I I don $t$ use public transit, so I would always vote no for anything involving a public transit improvement.

- Agree/Disagree

* Should taxes be increased for public transit improvements?

- What types of taxes should be increased to fund public transit improvements?

* Sales tax

* Property tax

* Gas tax

* D Does this transit system use its tax dollars effectively?

Other key issues given for not using transit, which were generated by focus groups in both Florida and the mid-west, are listed in Chapter 4 and are summarized here: 
* [ Service and convenience issues

- Hours of operation

- Reliability

- Frequency of transit vehicles

- Lack of flexibility versus using a personal automobile

- $\quad$ Need to make multiple transfers to complete trip

- Problems with using provided maps to navigate system

- Problems with using the system due to lack of knowledge about routes, schedules, operational hours, and fares

- Travel time

* $\mathrm{C}$ Safety issues

* D Discomfort with other passengers

* Fear of being a victim of crime while waiting at transit stop and/or while riding transit vehicle

* Problems with getting to stops due to roadway barriers (i.e., roadways not being pedestrian friendly)

* 7 Public image issues

* Class issues of using public transit

In summary, in designing an assessment strategy for any transit system, we must assess:

* What types of decisions must be made based upon the data collected,

* What types of people need to be included in this study,

${ }_{*}$ [ Will those willing to participate in the study provide an adequate sampling group?

* $\mathrm{C}$ How much money, time, and manpower resources will be required to complete the proposed design?

* W With regard to the design of survey questions, we need to ask if we could use the same questions used in other surveys, thereby making our survey comparable to other surveys.

\section{CHAPTER 7}

SUMMARY

Page 55 of 61 pages 
The primary objective of this report was to present an overview of the success of non-transit use in order to determine useful methods to attract choice riders. This report summarizes information on non-user and user demographics, and nation-wide transit studies designed to gather information on how to make public transit appeal to transit non-users.

\section{Summary of demographics}

Althought transit is available for most U.S. ctiziens, only a few utilize transit modes for work trips. Where transit is avaialble, less than three percent of the national owrking population uses it for work trips. Further, 28 percent of the population could, theoretically, use transit for work trips. However, only one percent of Florida s population use transit for work trips where it is available.

\section{Summary of Florida Community Public Transit Surveys}

The image of public transportation within Florida is positive, with most survey respondents viewing transit as a vital service to the community. Many Floridians see transit as an important part of solving transportation problems, supporting the local economy, and improving quality of life. However, these same people who support transit in theory may not be interested in riding it themselves or in paying more taxes to subsidize expansion of public transit.

Additionally, most respondents claimed that they were deterred from using transit because it is not convenient enough. The buses don $t$ come frequently enough, transit agencies don $t$ provide enough information on how to navigate the transit system schedule and routes, there are worries about personal safety, and finally, buses cannot offer the flexibility and comfort of a personal vehicle.

\section{Summary of Policy Recommendations}

Several policy changes are recommended in order to make public transit more attractive to automobile users. Non-users prefer the flexibility and time-savings of using their perso nal vehicles and any efforts to reduce personal automobile use will be met with resistance unless this breach in flexibility and convenience between public transit and personal vehicles.

It is important to address the concerns of convenience, safety, and social stigma as primary barriers to attracting non-users. The following list summarizes suggestions for policy changes and implementations which will be most effective in attracting non-user ridership to Florida public transit systems:

* Offering employer incentives to use public transit

* Combining park-and-rides with express services for commuters to ride from dense residential communities to high employment areas.

* [ Addressing safety concerns:

* Careful planning and consideration in choosing placement of transit stops as well as additional 
lighting and emergency telephones placed adjacent to bus stops as a barrier to crime while using transit.

* $[$ Adequate crossing areas, signage, and traffic signals to ensure pedestrian safety in accessing bus stops.

* A Addressing convenience concerns:

* $[$ Adding enhancements to Florida public transit systems such as

- express fixed-route service,

- dedicated bus lanes,

- bus stops near home and work,

- minimal transfers,

- no-wait transfers when necessary, and

- mini-van shuttle service from and to pick-up and discharge points within one block of origin and destination in order to attract more non-users to public transit.

* Florida public transit should offer user-friendly, interactive personal travel plans via the web and also via kiosks available at major transfer points.

* One study suggests that persons transporting children may be encouraged to use transit if they were offered such services as:

- guaranteed ride home,

- personal scheduling services, and

- discounted family fares.

* O Overcoming social stigma and generating more transit ridership among non-users:

* Marketing campaigns that minimize negative public perceptions and instill a sense of community responsibility are needed to promote a better image of public transit.

- Emphasizing the positives of using public transit is very important to minimizing perceptions of public transit stigma, that only those who cannot afford a car would use public transit.

- Better environmental health, less sprawl, and less traffic congestion are all good reasons to use public transit.

* Negative incentives to use public transit such as raising gasoline prices, road tolls, parking costs, and increased traffic congestion may increase transit ridership.

* T Transit systems must provide convenient service to places of interest. Enhancing bus service based upon activity center hours of operation and usage patterns.

* Websites could allow transit agencies the opportunity to market to non-users as well as using the website to answer FAQs and alleviate any concerns the possible transit user might have.

\section{Summary of survey methodology guidance}

When designing an assessment strategy for any transit system, the following questions must be answered:

${ }_{*}[\quad$ What types of decisions must be made based upon the data collect?

Page 57 of 61 pages 
* W What types of people need to be included in this study?

${ }_{*}[\quad$ Will those willing to participate in the study provide an adequate sampling group?

* How much money, time, and manpower resources will be required to complete the proposed design?

* W With regard to the design of survey questions, we need to ask if we could use the same questions used in other surveys, thereby making our survey comparable to other surveys. A listing of useful survey questions for transit system data gathering are summarized in Chapter 6. 


\section{REFERENCES}

Abdel-Aty M, Kitamura R, Jovanis P (1996) Investigating Effect of Advanced Traveler Information on Commuter Tendency to Use Transit. Transportation Research Record, Issue 1550: 65-72.

Bowers P (1998) Non-users Are Our Future. Mass Transit, Volume 24, Number 5: 90.

Broward County Transit Development Plan: 1995-1999. (1994) Tampa, FL: Center for Urban Transportation Research, 32-35.

Byrd J (1976) Characteristics, Attitudes, and Perceptions of Transit Nonusers in the Atlanta Region. Transportation Research Record, Issue 563: 29-37.

Casavant K, Painter K (1998) Demand Forecasting for Rural Transit. Seattle, Washington: Transportation Northwest (TransNow) and The Washington State Transportation Center (TRAC).

Cleland F (2002) Perceptions of Transit Safety. Tampa, FL: Center for Urban Transportation Research.

Conklin J, Halvorsen R, Fleishman D, Oram R (2002) Employer-Based Annual Transit pass Programs: A Survey of Current Practice in the Public Transit Industry. Paper presented at the $81^{\text {st }}$ Annual Transportation Research Board Meeting, January 13-17, Washington D.C., USA.

Cronin J (2002) An Evaluation of the Role of Marketing In Public Transportation Organizations. Paper presented at the $81^{\text {st }}$ Annual Transportation Research Board Meeting, January 13-17, Washington D.C., USA.

Dengler D (2000) San Diego Applies Competitive Positioning Analysis to Improve Transit. The Urban Transportation Monitor, July 7: 2.

Fielding G, Blakenship D, Tardiff T (1976) Consumer Attitudes Toward Public Transit. 
Transportation Research Record, Issue 563: 22-28.

Fujii S, Kitamura R (2002) What does a one-month bus ticket do to habitual drivers? An experimental analysis of habit and attitude change. Paper presented at the $81^{\text {st }}$ Annual Transportation Research Board Meeting, January 13-17, Washington D.C., USA.

Hardin J (2001) Assessment of Operational Barriers and Impediments to Transit Use: Transit Information and Scheduling for Major Activity Centers. Tampa, FL: Center for Urban Transportation Research.

Horton J, Gillig L (1997) TDM and the Internet. Paper presented at the $14^{\text {th }}$ Annual Southeast Regional Commuter Transportation Conference, March 10, New Orleans, USA.

Ingalls G, Hartgen D, Owens T (1994) Public Fear in Crime and Its Role in Bus Transit Use. Transportation Research Record, Issue 1433: 201-211.

Kane A (2001) Moving Ahead: The American Public Speaks On Roadways and Transportation in Communities. Federal Highway Administration report, Publication Number FHWA-OP01-017.

Lee H, Schmeltz J, Johnson P (1982) A Study of Users and Non-Users of the Oshkosh Transit System. Oshkosh, WI: University of Wisconsin System.

Litman T (1996) Public Transit Benefits in the Victoria Region. Victoria, British Columbia: Victoria Transport Policy Institute.

Livinson H (2000) Bus Transit in the $21^{\text {st }}$ Century-Perspectives and Prospects. Paper presented at the Transportation Research Board Annual Meeting, January 8-11, Washington D.C., USA.

Manatee County Transit Development Plan: 1995-2000. (1995) Tampa, FL: Center for Urban Transportation Research, 57-58. 
Mierzejewski E, Ball W (1990) New Findings on Factors Related to Transit Use. Institute of Transportation Engineers Journal, February: 34-39.

Oran R, Stark S (1996) Infrequent Riders: One Key to New Transit Ridership and Revenue. Transportation Research Record, Issue 1521: 37-41.

Polzin S (2000) Public Transportation in the $21^{\text {st }}$ Century: Challenges and Opportunities in Florida. Paper presented at the Transpo2000-The Future is Now! Conference, April 1719, Kissimmee, USA.

Reed T, Wallace R, Rodriguez D (1999) Transit Passenger Perceptions Regarding TransitRelated Crime Reduction Measures. Transportation Research Board Submit.

Reese R, Daley J, Stanton W (1980) Differences in Perceptions and Attitudes of Bus Riders and Non-riders in a Southern City. Logistics and Transportation Review, Volume 17, Issue 4: 416-427.

Regional Transportation Master Plan Waterloo Public Opinion Survey Results. Survey completed July 1997 by Angus Reid Group for Region of Waterloo, Canada. Http://www.region.waterloo.on.ca/roads/docs/mpsurveys.html

Ridley T (2000) Is an Integrated Transport Policy a Realistic Possibility? Lecture presented at the RSA at University of London Bristol, May 30, London, England. Http://www.sagersa.org.uk/lectures/texts/tonyridley.html

Thomson T, Bakr M, Makowski G (1976) Non-user preference for Improvements and Attitude Towards Future Use of a Bus System. Socio-Economic Planning Sciences, Volume 11, Issue 2: 61-76.

Transit System Non-Ridership Study. Survey and final report completed March 2000 by Periscope for MetroTransit in Minneapolis, Minnesota.

Weiss D (1974) Citizen Opinions on Public Transportation Roles, Service, and Financing. Transportation Research Record, Issue 590: 5-8. 